\title{
Mesenchymal Stem Cells Provide an Advantageous Tumor Microenvironment for the Restoration of Cancer Stem Cells
}

\author{
Kanako Nishimura $^{\mathrm{a}}$ Shuho Semba $^{\mathrm{a}}$ Kazuhiko Aoyagi $^{\mathrm{b}}$ Hiroki Sasaki $^{\mathrm{b}}$ \\ Hiroshi Yokozaki ${ }^{a}$ \\ ${ }^{a}$ Division of Pathology, Department of Pathology, Kobe University Graduate School of Medicine, Kobe, and \\ ${ }^{b}$ Division of Integrative Omics and Bioinformatics, Innovative Pathophysiology Research Group, National Cancer \\ Center Research Institute, Tokyo, Japan
}

\section{Key Words}

Bone-marrow-derived mesenchymal stem cells $\cdot$ Cancer stem cell $\cdot$ Gastric carcinoma $\cdot$ Tumor microenvironment

\begin{abstract}
Objective: Accumulating evidences suggest that cancer-associated fibroblasts are provided from bone-marrow-derived mesenchymal stem cells (BM-MSCs); however, little is known about the mechanism(s) by which BM-MSCs accelerate cancer aggressiveness. Methods: Gastric carcinoma (GC)-derived MKN-7 cells were cocultured with UE6E7T-12 BM-MSCs. The gene expression profile in MKN-7 cells was investigated by microarray analysis. Between two major types of GCs (intestinal- and diffuse-type), the expression of genes was detected by immunohistochemistry. Results: We found that direct attachment to UE6E7T-12 induced proliferation and cluster formation of MKN-7 cells. Coculture with UE6E7T-12 increased the population of CD133+ MKN-7 cells in vitro and coimplantation of these in mice resulted in subcutaneous tumors in vivo. The wingless-type MMTV integration site (WNT) family member 5A (WNT5A) and transforming growth factor- $\beta$ (TGF- $\beta$ )-induced (TGFBI) genes were found to be upregulated in MKN-7 cells directly attached to UE6E7T-12. Recruitment of CD271+ BM-MSC was detected preferentially
\end{abstract}

in the stroma of the diffuse-type GC and this type of GC cell also showed frequent expression of WNT5A, TGF- $\beta$ type I receptor and CD133. Conclusion: BM-MSC-mediated activations of the WNT and TGF- $\beta$ signaling pathways were thought to provide advantageous microenvironments for cancer progression by supporting the reacquisition and maintenance of cancer stem cells.

Copyright $\odot 2012$ S. Karger AG, Basel

\section{Introduction}

Myofibroblasts in the stroma of various human carcinomas, collectively termed cancer-associated fibroblasts (CAFs), play an important role in providing a microenvironment where cancer cells increase their aggressiveness and resistance to chemotherapy [1-3]. At the invasive front of tumors, cancer cells contact CAFs by interaction between integrins on the cells and their ligands, vascular cell adhesion molecule-1 or intercellular adhesion molecule-1, expressed on the CAFs $[4,5]$. In addition, soluble factors including stromal cell-derived factor-1 (SDF-1) secreted by CAFs induce the proliferation, invasiveness and antiapoptotic-factor expression in cancer cells in a paracrine manner $[6,7]$. Thus, the microenvironment for the

\section{KARGER}

Fax +4161306 1234 E-Mail karger@karger.ch www.karger.com
(C) 2012 S. Karger AG, Basel

1015-2008/12/0796-0290\$38.00/0

Accessible online at:

www.karger.com/pat
Shuho Semba

Division of Pathology, Department of Pathology

Kobe University Graduate School of Medicine

7-5-1 Kusunoki-cho, Chuo-ku, Kobe 650-0017 (Japan)

Tel. +81 78382 5461, E-Mail semba@ @ed.kobe-u.ac.jp 
acceleration of cancer cell invasion, metastasis and resistance to anticancer drugs involves intricate communications of mesenchymal fibroblasts with cancer cells, either directly or indirectly or both. According to gene expression profiling-based similarities with CAFs, mesenchymal stem cells (MSCs) are considered to be a source of CAFs $[8,9]$; however, little is known about the biological significance of bone-marrow-derived MSCs (BM-MSCs) in the formation of tumor microenvironments. In general, BM-MSCs are able to differentiate into a number of mesenchymal phenotypes including those forming bone, cartilage, muscle, fat, neurons and other connective tissues [10-12]. In a mouse model, BM-MSC-treated wounds exhibited significantly accelerated wound closure with increased reepithelialization, cellularity and angiogenesis [13]. These findings have raised the possibility of BMMSCs contributing to the maintenance of the tumor microenvironment via CAFs.

Cells within the tumor population itself exhibit functional heterogeneity with distinct proliferative and differentiative capacities [14]. Two models have been proposed to account for such tumor heterogeneity. The clonal evolution model (also referred as the stochastic model) postulates that mutant tumor cells with a growth advantage are selected and expanded, with cells in the dominant population having a similar potential for regenerating tumor growth [15], while the cancer stem cell (CSC) model (also referred as the hierarchical model) is the concept that only CSCs can generate a tumor, based on their selfrenewal properties and enormous proliferative potential through their activation or progenitor production [16]. With new insights into the cellular mechanisms leading to cancer, the metastatic potential of tumor cells is thought to be a reflection of the ability of CSCs to clonally initiate tumorigenicity at distant sites $[17,18]$. Taken together with the fact that dormant CSCs in the $\mathrm{G}_{0}$ phase of the cell cycle are potentially more resistant to chemotherapy and irradiation [19], to acquire an understanding of CSCs is urgent, not only for cancer prevention but also for the development of novel therapeutic approaches against cancer. Cell surface markers CD44 [20], CD24 [21], epithelial cell adhesion molecule (EpCAM) [20], ATP-binding cassette $\mathrm{B} 5$ (ABCB5) [22] or the combination of these molecules have been exploited to support the CSC model. Recently, evidence has accumulated that CD133 is widely available as a CSC marker in a large variety of human malignancies, including those of the brain, colon, liver, pancreas and prostate [23-27]. CD133 is a 5-transmembranedomain glycoprotein, originally identified as a cell surface antigen present on CD34+ hematopoietic stem cells [28], and the antibody against the CD133 epitope is now therefore exploited to distinguish CSCs that compose a minor population within a tumor mass [29].

However, the CSC paradigm becomes confusing. First, the influence of an appropriate microenvironment is ignored in the mouse xenograft model when evaluating the tumor-initiating capacity of human cancer cells. Recently, long-term culture conditions containing the winglesstype MMTV integration site (WNT) agonist R-spondin 1 , epidermal growth factor (EGF), Noggin and lamininrich matrigel were established, in which crypt-villus organoids developed from single colon stem cells [30]. These results strongly support the importance of mimicking a mesenchymal niche for the maintenance and differentiation of tissue-specific stem cells. Second, it is possible that a subpopulation of cells that appears to be nontumorigenic might actually be tumorigenic in the presence of a suitable niche. In single-cell transplants, an average of $27 \%$ of unselected melanoma cells from 4 different patients formed tumors in nonobese diabetic (NOD)/severe combined immunodeficiency (SCID) interleukin-2 receptor gamma chain null (Il2 $\left.\mathrm{rg}^{-/}\right)$mice [31]. In this study, we comaintained gastric carcinoma (GC) cells and BM-MSCs in vitro and in vivo to examine the possible roles of BM-MSCs for the acceleration of tumor growth and restoration of CSCs. Furthermore, we attempted to identify the intrinsic molecules for the reacquisition of gastric CSCs in such a circumstance. Our findings propose a model of bidirectional interconvertibility of cancer cells between CSCs and non-CSCs by a BM-MSC-mediated tumor microenvironment.

\section{Materials and Methods}

\section{Cell Lines}

Human GC-derived MKN-7 cells were kindly provided by Professor T. Suzuki (Fukushima Medical University, Fukushima, Japan) and UE6E7T-12 BM-MSCs were obtained from the Japan Health Science Foundation (Tokyo, Japan). MKN-7 cells were established from a 39-year-old male patient with highly differentiated intestinal-type GC [32]. UE6E7T-12 BM-MSCs from a 91-year-old male were immortalized by infecting retrovirus encoding Bmi-1, human papillomavirus E6 and E7 and human telomerase reverse transcriptase genes [33]. Differentiated UE6E7T-12 BM-MSCs were maintained in RPMI-1640 for 30 days, and NF-23 fibroblasts (kindly provided by Professor K. Hirakawa, Osaka City University, Osaka, Japan) were established from a 77-year-old male patient with early GC who had distal gastrectomy. MKN-7 cells and NF-23 fibroblasts were routinely maintained in RPMI-1640 supplemented with $10 \%$ fetal bovine serum, and UE6E7T-12 BM-MSCs were cultured in MSC-MB (Takara Bio, Ohtsu, Japan). 


\section{Cell Treatment and Gene Transfection}

MKN-7 cells were treated with recombinant WNT5A (500 ng/ $\mathrm{ml}$; Sigma, St. Louis, Mo., USA) and TGF- $\beta 1$ (10 ng/ml; Sigma) for $48 \mathrm{~h}$. Also, WNT inhibitor XAV939 (Sigma) and TGF- $\beta$ inhibitor SB431542 (Sigma) were dissolved in dimethyl sulfoxide at final concentrations of $1 \mu \mathrm{M}$ and $50 \mathrm{pM}$, respectively. We found that the final concentration of dimethyl sulfoxide used did not affect cell survival and proliferation. For labeling of UE6E7T-12 BM-MSCs, adenoviruses carrying green fluorescent protein [GFP (Ad-GFP); Qbiogene, Carlsbad, Calif., USA] were infected $24 \mathrm{~h}$ prior to experiments at a multiplicity of infection (MOI) of 10. The neutralizing antibody against SDF-1 (10 mg/ml; Cell Signaling, Beverly, Mass., USA) was added to the coculture of MKN-7 cells and UE6E7T-12 BM-MSCs.

\section{Cell Separation with Magnetic Cell Sorting}

From the coculture of MKN-7 cells and UE6E7T-12 BMMSCs, EpCAM+ cells derived from MKN-7 cells were sorted using the autoMACS Cell Separation (Miltenyi, Auburn, Calif., USA). Briefly, cells were incubated for $30 \mathrm{~min}$ with magnetic beads precoated with anti-EpCAM antibody (Miltenyi). EpCAM bead-bound cells were washed 3 times with PBS and incubated with DNase I to release the cells from the beads via DNA linker cleavage. The flow-through was collected and considered as stromal cells. Similarly, CD133+ MKN-7 cells were sorted using antiCD133 antibody (Miltenyi).

\section{Flow Cytometric Analysis}

To analyse cellular DNA content, cells sorted with magnetic cell sorting (MACS) were fixed in 70\% methanol, treated with RNase A and stained with propidium iodide. The analysis was performed with a fluorescence-activated cell-sorting (FACS) Calibur cytometer (BD Biosciences, San Jose, Calif., USA). Experiments were conducted 3 times.

Cell Attachment, Growth and Aggregation in Soft Agar

After coincubation of the MKN-7 cells and the MSCs at a density of $1 \times 10^{4}$ cells in $100-\mathrm{mm}$ plates, the MKN-7 cells directly attached were counted. For growth test, EpCAM+ MKN-7 cells were separated with MACS. We counted the number of the cells with a cell-counting chamber. To analyze the effect of cell-cell interaction, the conditioned medium of UE6E7T-12 BM-MSCs were replaced with MSC-BM. Agar (Nakalai Tesque, Kyoto, Japan) was dissolved in culture medium to $0.5 \%$ and plated in 6-well plates (bottom layer). Cells (MKN-7 cells, UE6E7T-12 BM-MSCs and the mixture of both) were seeded at $1 \times 10^{4}$ cells per well in $0.3 \%$ agar (top layer) over bottom layer. Cells were covered with liquid growth media, and cultured for $72 \mathrm{~h}$. Numbers of cell clusters ( $>10$ cells) were counted.

\section{Reverse-Transcription Polymerase Chain Reaction}

RT-PCR was performed with a OneStep RT-PCR assay kit (Qiagen, Hilden, Germany). The primer sets used in this study are as follows: E-cadherin, 5'-TGC CCA GAA AAT GAA AAA GG3'/5'-GTG TAT GTG GCA ATG CGT TC-3'; Keratin 8, 5'-ACC AGG AGC TGA TGA ACG TC-3'/5'-AGC TGT TCA CTT GGG CAG G-3'; Keratin 14, 5'-GAG AAG GTG ACC ATG CAG AA3'/5'-ACA TTG ACA TCT CCA CCC AC-3'; MUC1, 5'-CCG CCG AAA GAA CTA CGG-3'/ $/ 5^{\prime}$-AAG TTG GCA GAA GTG GC-3'; MUC2, 5'-AAG TTG GCA GAA GTG GC-3'/5'-GAC CAC GGC
CCC GTT AAG CA-3'; vimentin, 5'-GAG AAC TTT GCC GTT GAA GC-3'/5'-TCC AGC AGC TTC CTG TAG GT-3'; Snail, 5'ACC ACT ATG CCG CGC TCT T-3'/5'-GGT CGT AGG GCT GCT GGA A-3'; CD44, 5' -CAG TCA CAG ACC TGC CCA ATG3'/5'-AAC CTC CTG AAG TGC TGC TCC-3'; CD133, 5'-TCC ACA GAA ATT TAC CTA CAT TGG-3'/5'-CAG CAG AGA GCA GAT GAC CA-3', and glyceraldehyde-3-phosphate dehydrogenase $(G A P D H), 5^{\prime}$-TCC ACT GGC GTC TTC ACC-3'/5'-GGC AGA GAT GAT GAC CCT TTT-3'. Each 25- $\mu$ l reaction mixture containing $10 \mathrm{ng}$ of total RNA was amplified for 30 cycles with the following regimen: $\mathrm{RT}$ at $50^{\circ} \mathrm{C}$ for $30 \mathrm{~min}$; denaturation at $94^{\circ} \mathrm{C}$ for $30 \mathrm{~s}$; annealing at $58^{\circ} \mathrm{C}$ for $30 \mathrm{~s}$ and extension at $72^{\circ} \mathrm{C}$ for $1 \mathrm{~min}$.

Quantitative Real-Time RT-PCR

Quantitative real-time RT-PCR was performed using a QuantiTect SYBR Green PCR kit (Qiagen) in triplicates. The primer sets used in this study are as follows: WNT5A, $5^{\prime}$-ATT CAC ATC CCC TCA GTT GC-3'/5'-CCA TTT GGA ATA AGC CTT TCG-3'; TGFBI, 5'-GCC TGG GCG ACA AGA TTG A-3'/5'-CCA ACA GCT CCC AAT TCA C-3'; Slug, 5'-ATG CCG CGC TCC TTC CT3'/5'-TGT GTC CAG TTC GCT-3'; AKT3, 5'-ATG AGC GAT GTT ACC ATT GT-3'/5'-CAG TCT GTC TGC TAC AGC CTG GAT A-3'; ID3, 5' -CTC CAC GCT CTG AAA AGA CC-3' $15^{\prime}$-ACT CAG ATT AAG CCA GGT GGA-3'; CD133, 5'-TCC ACA GAA ATT TAC CTA CAT TGG-3'/5'-CAG CAG AGA GCA GAT GAC CA-3', and GAPDH, 5'-TCC ACT GGC GTC TTC ACC-3'/5'-GGC AGA GAT GAT GAC CCT TTT-3'. Thermal cycling was performed with an ABI StepOne real-time PCR system (Applied Biosystems, Foster City, N.J., USA). The CT values were determined by plotting the observed fluorescence against the cycle number. Each CT value was analyzed using the comparative threshold cycle method and normalized to the CT values of GAPDH. The relative gene expression levels were estimated using the following formula: relative expression $=2-\left(\mathrm{CT}^{[\text {target gene }]}-\mathrm{CT}^{[G A P D H]}\right)$.

\section{Immunocytochemistry}

Cells in chamber slides were fixed with $4 \%$ formalin and incubated with blocking solution containing $1 \%$ bovine serum albumin in PBS. Antibodies used in this study were as follows: anti-Ecadherin (Santa Cruz Biotechnology, Santa Cruz, Calif., USA), anti-MUC1 (BD Biosciences), anti-MUC2 (BD Biosciences), antiChromogranin A (Dako, Glostrup, Denmark), anti-villin (Sigma), anti-vimentin (Sigma), anti-Snail (Cell Signaling), antiCD10 (Dako), anti-CD133 (Miltenyi), anti-TGF- $\beta 1$ (BD Biosciences), anti-WNT5A (Abcam, Cambridge, Calif., USA), anti- $\beta$ catenin (Cell Signaling) and anti-Smad4 (Cell Signaling). Cells were incubated with primary antibody for $2 \mathrm{~h}$ and then incubated with Cy2- and Cy3-conjugated anti-rabbit/mouse IgGs. Cells were mounted in 4',6-diamidino-2-phenylindole (DAPI)-containing agent (Vector, Burlingame, Calif., USA) and examined using a fluorescence microscope.

\section{Immunohistochemistry}

A total of 40 cases of human GC tissues (20 each of diffusetype and intestinal-type GC) surgically removed at Kobe University Hospital (Kobe, Japan) were employed. Informed consent was obtained from all patients and the study was approved by the institutional review committee of Kobe University. Histological examination was performed according to the Japanese Classifi- 
cation of Gastric Carcinoma [34]. Tissue sections (4- $\mu \mathrm{m})$ of formalin-fixed and paraffin-embedded human GCs were used. Antibodies against CAM5.1 (Dako), CD271 (Miltenyi), WNT5A (Abcam) and TGFBR1 (Santa Cruz Biotechnology) were used. After visualization of each signal with $\mathrm{Cy} 2$ - and $\mathrm{Cy} 3$-conjugated anti-rabbit/mouse IgGs, sections were counterstained with DAPI.

\section{Mouse Xenograft Model}

Tumorigenicity was determined by subcutaneous injection of MKN-7 cells into the right flank of SCID mice (Japan Clea, Tokyo, Japan) in the presence or absence of equivalent numbers of UE6E7T-12 BM-MSCs with a 1:1 ratio of matrigel. Hematoxylin and eosin staining was carried out on paraffin-embedded sections following standard protocols to confirm the development of subcutaneous tumors. Tumor volume $(V)$ was calculated using the following equation: $V=\left(a^{2} \times b\right) / 2$, where $a$ is the width of the tumor (small diameter) and $b$ is the length (large diameter), both in millimeters. Also, CD133+ and CD133- MKN-7 cells after treatment with recombinant WNT5A and TGF- $\beta$ were injected into SCID mice subcutaneously with a 1:1 ratio of matrigel. We also examined the incidence of subcutaneous tumor. The initiating cell frequency was calculated using extreme limiting dilution analysis (ELDA) software. ELDA is suitable for any limiting dilution problem, but special methods are implemented to give reliable results in extreme data situations, e.g. when all the assays give positive or negative results (http://bioinf.wehi.edu.au/software/ elda/).

\section{Microarray Analysis}

MKN-7 cells (original, CD133+ and CD133-), maintained in the presence or absence of UE6E7T-12 BM-MSCs, were collected. The cell pellets were dissolved in TRIzol reagent (Invitrogen, Carlsbad, Calif., USA) and were homogenized, and then total RNAs were extracted. For microarray analysis, we used Human Genome U133A Arrays (Affymetrix, Santa Clara, Calif., USA). Target cRNA was generated from 100 ng of total RNA from each sample with Two-Cycle Target Labeling and Control Reagents (Affymetrix). The procedures for target hybridization, washing and staining with signal amplification were conducted in accordance with the manufacturer's instructions. The arrays were scanned with a GeneChip Scanner 3000 (Affymetrix), and the intensity of each feature of the array was calculated with GeneChip Operating Software v1.1.1 (Affymetrix). The average intensity was standardized to the target intensity, which was set equal to 1,000 to reliably compare variable multiple arrays. The values were log-transformed and median-centered. GeneSpring (Agilent Technologies, Santa Clara, Calif., USA) were used for gene selection. The upregulated and downregulated genes $(>2$-fold) were selected. Expression of 5 differentially expressed genes, which were identified by the microarray analysis, was confirmed by realtime RT-PCR.

\section{Enzyme-Linked Immunosorbent Assay}

Cells (MKN-7 cells, UE6E7T-12 BM-MSCs and a mixture of both) were seeded $4 \times 10^{5}$ per well and incubated for $48 \mathrm{~h}$. Medium was collected, centrifuged at $1,000 \mathrm{~g}$ for $5 \mathrm{~min}$ and supernatant was stored at $-80^{\circ} \mathrm{C}$ until assayed. The concentration of TGF$\beta 1$ was calculated by comparison to a standard curve obtained by plotting the absorptions versus the corresponding concentrations of the known standard. Assays were conducted according to the manufacturer's instructions (Human Biotrak Easy ELISA; GE Healthcare, Buckinghamshire, UK). An absorbance reading was taken at $450 \mathrm{~nm}$ using a microwell plate reader. Experiments were performed in triplicate and the results were the average of 3 independent experiments.

\section{Results}

\section{BM-MSCs Provide an Advantageous Scaffold for GC Cells}

To investigate the biological impacts of the cell culture condition formed by BM-MSCs, human GC-derived MKN-7 cells were incubated with human UE6E7T-12 BMMSCs. Prior to the experiments, we confirmed that the replacement of RPMI-1640 medium with MSC-BM, a conditioned medium for BM-MSCs, had no significant effect on MKN-7 cells (online suppl. fig. S1; for all online suppl. material, see www.karger.com/doi/10.1159/000337296). When coincubated, MKN-7 cells showed direct contact with original UE6E7T-12 BM-MSCs at a relatively high rate (fig. 1a, b). To make sure that these cell clusters had originated from MKN-7 cells, UE6E7T-12 BM-MSCs were labeled with GFP: GFP-labeled UE6E7T-12 BM-MSCs demonstrated incremental development of fibroblast-like morphology $72 \mathrm{~h}$ after coincubation (fig. 1c). To assess the peculiarity of the effect of original UE6E7T-12 BM-MSCs, the coincubation experiment was performed with differentiated UE6E7T-12 BM-MSCs or NF-23 gastric fibroblasts. Interestingly, the percentages of cell-cell contact with MKN-7 cells significantly decreased when differentiated UE6E7T-12 BM-MSCs or NF-23 fibroblasts were substituted for original BM-MSCs (fig. 1a, b). Since SDF-1 secreted from stromal cells promotes centripetal migration of cancer cells [35], the neutralizing antibody against SDF1 was added into the culturing medium; however, the antiSDF-1 antibody showed no evidence of inhibiting cell-cell contact between MKN-7 cells and UE6E7T-12 BM-MSCs (fig. 1b). On soft agar plates, MKN-7 cells exhibited a tumor sphere-like structure with the placement of a GFPlabeled UE6E7T-12 BM-MSC at the core of each cluster, which was significantly different from the evidences of cell aggregations in MKN-7 cells and UE6E7T-12 BM-MSCs themselves (fig. 1d, e).

\section{Coculture with BM-MSCs Increases GC Cell Growth}

To investigate the growth-promoting effect of BMMSCs on GC cells, the number of MKN-7 cells which were separated with the anti-EpCAM antibody was calculated, because EpCAM is expressed in MKN-7 cells 


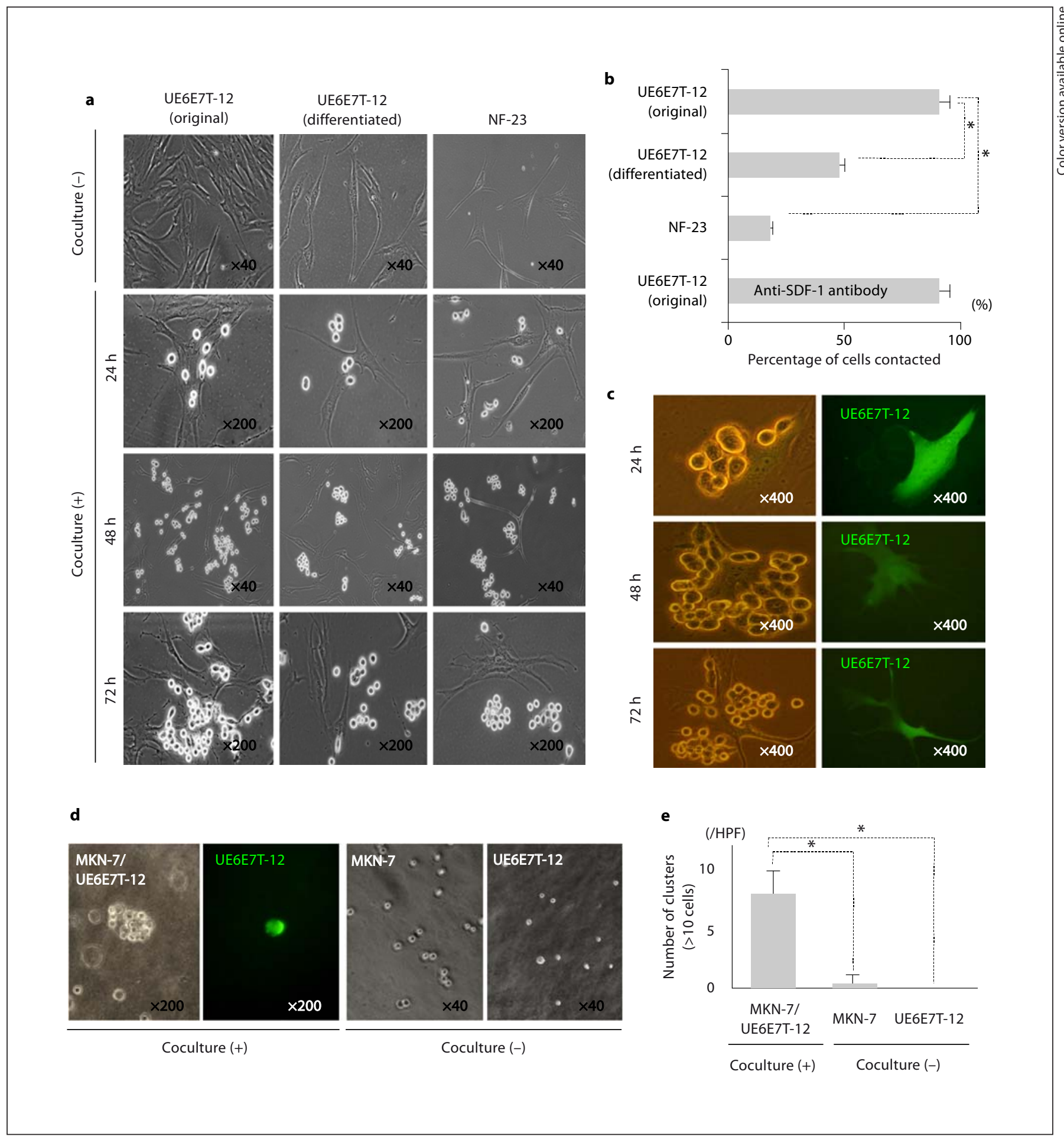

Fig. 1. Coculture of GC-derived MKN-7 cells with UE6E7T-12 BM-MSCs. a Representative images of MKN-7 cells coincubated with UE6E7T-12 BM-MSCs (original and differentiated) or NF-23 fibroblasts. The MSCs exhibited fibroblast-like spindle morphology. b Percentages of MKN-7 cells contacted with the MSCs. The neutralizing antibody against SDF-1 $(10 \mu \mathrm{g} / \mathrm{ml})$ was added to the culturing medium. ${ }^{*} \mathrm{p}<0.05$. c Coincubation of MKN-7 cells with the GFP-labeled UE6E7T-12 BM-MSCs. Ad-GFP were infected into the BM-MSCs $24 \mathrm{~h}$ prior to the experiment. d Representative images of cell aggregation assay in soft agar plates. MKN-7 cells, GFP-labeled UE6E7T-12 BM-MSCs and the mixture of both lines were maintained in soft agar plates for $72 \mathrm{~h}$. e Results of cell aggregation assay. Numbers of cell clusters ( $>10$ cells) were counted $72 \mathrm{~h}$ after coincubation. ${ }^{*} \mathrm{p}<0.05$. 
Fig. 2. Coculture with UE6E7T-12 BMMSCs stimulates growth of MKN-7 cells. a Representative images of coculture of MKN-7 cells and UE6E7T-12 BM-MSCs. b Results of flow cytometric analysis of MKN-7 cells. The effect of the conditioned medium of UE6E7T-12 BM-MSCs (UE6E7T-12 sup.) was also tested. Percentages of each fraction $\left(G_{0} / G_{1}, S\right.$ or $\mathrm{G}_{2} / \mathrm{M}$ ) are shown in the right upper corner of each fluorogram. c Cell growth test of MKN-7 cells. At each time point, cells were trypsinized, separated with MACS with antibody against EpCAM and then counted. ${ }^{*} \mathrm{p}<0.05$. a

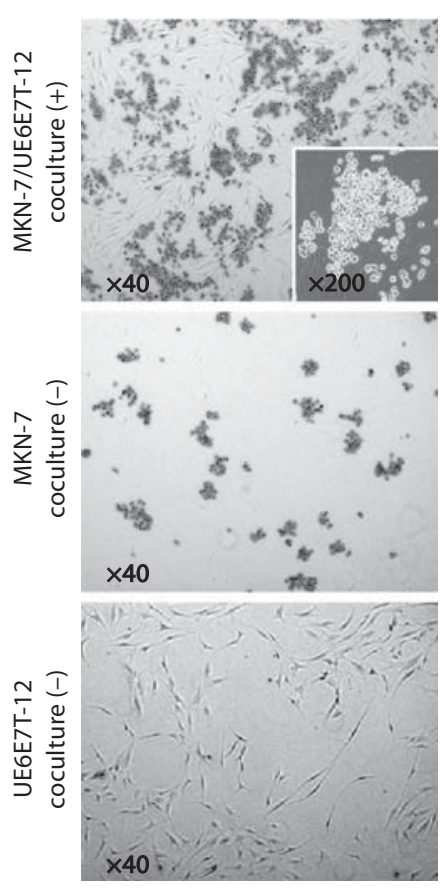

b
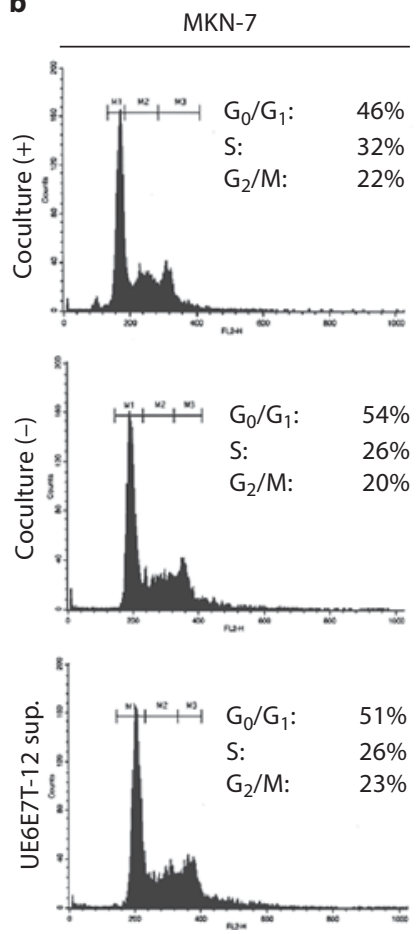

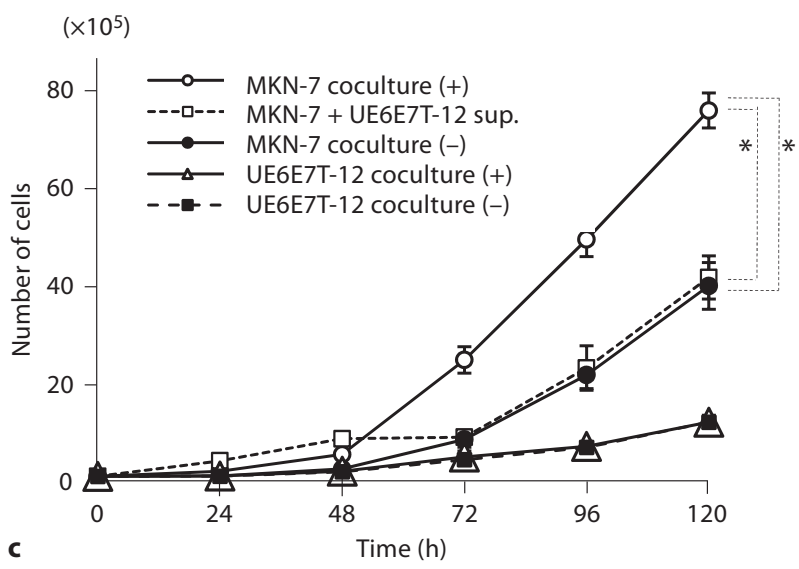

but not in UE6E7T-12 BM-MSCs (online suppl. fig. S2). Forty-eight hours after the coincubation, the number of MKN-7 cells in the $S$ and $G_{2} / M$ phases was significantly increased when the cells were coincubated with UE6E7T-12 BM-MSCs, whereas no significant change was detected when they were maintained in the UE6E7T12-conditioned medium (fig. 2a, b). Accordingly, the growth of MKN-7 cells was dramatically activated only when the cells were comaintained with UE6E7T-12 BMMSCs (fig. 2c); however, in turn, MKN-7 cells did not have any impact on the proliferation and gene expression of the UE6E7T-12 BM-MSCs (fig. 2c, online suppl. fig. S3). Taken together, these findings indicated that direct contact with BM-MSCs contributed to the formation of an advantageous scaffold for the proliferation of GC cells. 
Fig. 3. Direct contact with UE6E7T-12 BM-MSC upregulates population of CD133+ MKN-7 cells. a Differential expression of epithelial (E-cadherin, Keratin 8, Keratin 14, MUC1 and MUC2), mesenchymal (vimentin and Snail) and CSC markers (CD44 and CD133) in MKN-7 cells by RT-PCR analysis. $G A P D H$ was used as a control. b Immunocytochemistry of E-cadherin, MUC1, vimentin, Snail and CD133 in MKN-7 cells in the presence or absence of coculture with UE6E7T-12 BM-MSCs. Nuclei were visualized by DAPI. Inset Membranous localization of CD133 protein. c Coculture with UE6E7T-12 BM-MSCs increases CD133+ MKN-7 cells in vitro. CD133+ and CD133MKN-7 cells were maintained for $48 \mathrm{~h}$ in the presence or absence of UE6E7T-12 BM-MSCs and the isolated MKN-7 cells were divided into CD133+ and CD133cells. d Localization of CD133+ MKN-7 cells in coculture with UE6E7T-12 BMMSCs in vitro. e Morphological properties of CD133+ and CD133- MKN-7 cells examined by electron microscopy.

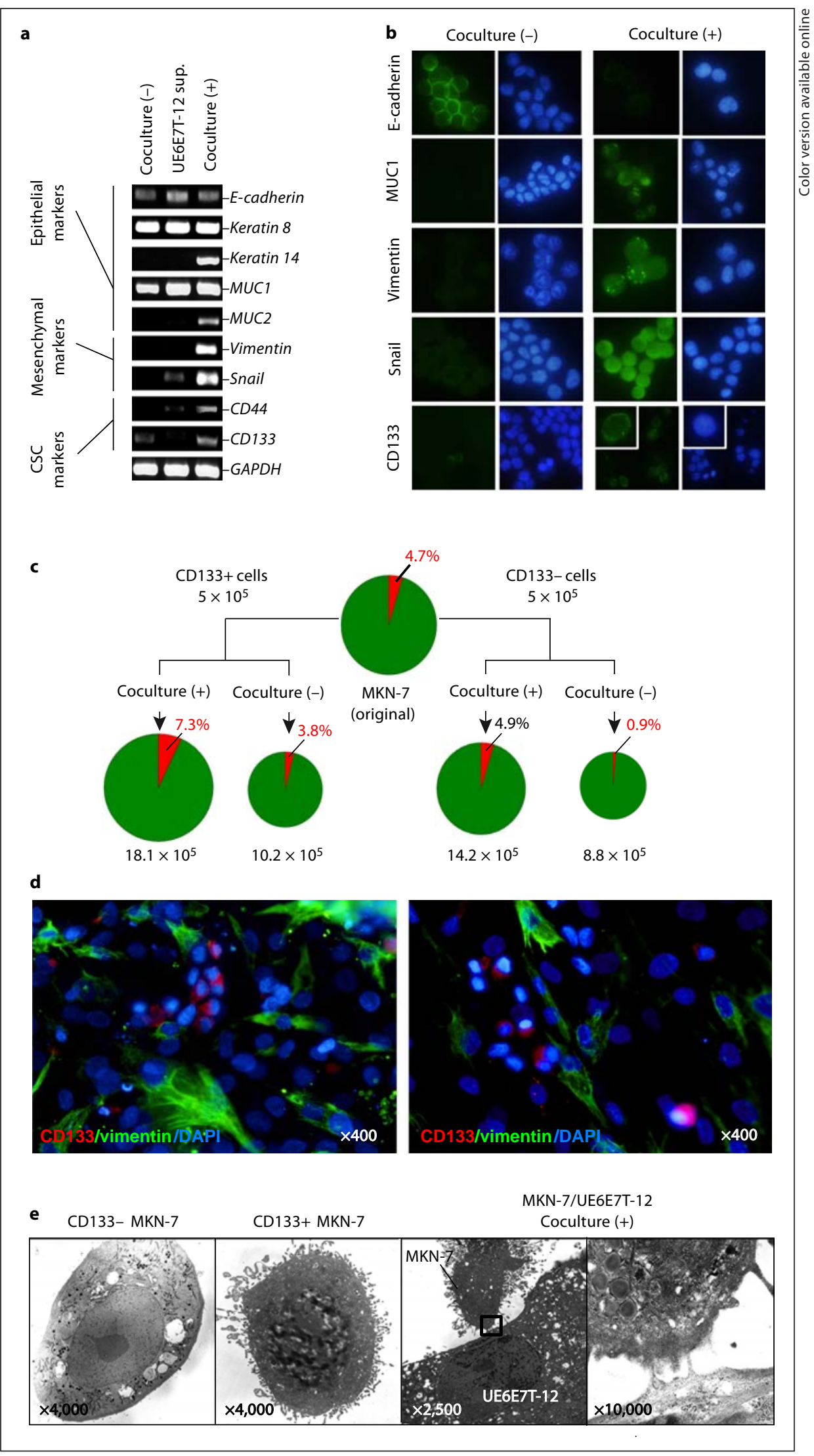


Table 1. Subcutaneous in vivo tumor development experiments of MKN-7 cells, UE6E7T-12 BM-MSCs and the mixture of both in SCID mice

\begin{tabular}{llll}
\hline Cells per injection & $\begin{array}{l}\text { MKN-7/UE6E7T-12 } \\
\text { (coinjection) incidence (\%) }\end{array}$ & $\begin{array}{l}\text { MKN-7 } \\
\text { incidence (\%) }\end{array}$ & $\begin{array}{l}\text { UE6E7T-12 } \\
\text { incidence (\%) }\end{array}$ \\
\hline $1 \times 10^{7}$ & $4 / 4(100)$ & $4 / 4(100)$ & $0 / 4(0)$ \\
$1 \times 10^{6}$ & $4 / 4(100)$ & $4 / 4(100)$ & $0 / 4(0)$ \\
$1 \times 10^{5}$ & $4 / 4(100)$ & $4 / 4(100)$ & $0 / 4(0)$ \\
$1 \times 10^{4}$ & $4 / 4(100)$ & $3 / 4(75)$ & $0 / 4(0)$ \\
$1 \times 10^{3}$ & $3 / 4(75)$ & $2 / 4(50)$ & $0 / 4(0)$ \\
\hline Frequency & $1 / 722$ & $1 / 4,579$ & - \\
Folds change & $1 / 213-1 / 2,454$ & $1 / 532-1 / 13,691$ & - \\
\hline
\end{tabular}

SCID mice were injected with $1 \times 10^{3}, 1 \times 10^{4}, 1 \times 10^{5}, 1 \times 10^{6}$ and $1 \times 10^{7}$ cells. Mice were monitored for 4 weeks and scored as positive (palpable tumor) or negative. Establishment of xenografts was evaluated by histological examination.

\section{Coculture with BM-MSCs Upregulates CD133+ GC Cells}

Next, altered gene expressions in MKN-7 cells in the presence or absence of UE6E7T-12 BM-MSCs or treated with a conditioned media of UE6E7T-12 BM-MSCs were examined, with the intention of specifically examining the epithelial-mesenchymal transition (EMT) and the restoration of CSCs. By coculturing with BM-MSCs, induction of the EMT supported by decreased levels of E-cadherin and increased levels of vimentin and Snail were detected as well as the restoration of CSC markers CD44 and CD133 (fig. 3a). The results were also followed by immunofluorescence (fig. 3b). To further test the idea that BMMSCs are potentially able to restore CSCs, we counted the populations of $\mathrm{CD} 133+$ and $\mathrm{CD} 133-\mathrm{MKN}-7$ cells. In the original culture, $4.7 \%$ of the cells were of CD133+ MKN-7 cells; at $48 \mathrm{~h}$ after coincubation with UE6E7T-12 BMMSCs, the percentages of CD133+ cells within CD133+ and CD133-MKN-7 cells were 7.3 and 4.9\%, respectively, which was higher than those in the cells maintained without coculture with UE6E7T-12 BM-MSCs (fig. 3c). Indeed, CD133+ MKN-7 cells were found particularly near to co-ncubated BM-MSCs (fig. 3d). By electron microscopy, CD133+ MKN-7 cells exhibited a microvilli structure at the cell surface, which was also observed in MKN7 cells showing cohesiveness with UE6E7T-12 BM-MSCs (fig. 3e). Taken together with the data that support the validity of CD133 as a CSC marker in MKN-7 cells evaluated by the tumorigenicity test in mouse subcutaneous xenografts (online suppl. fig. S4), BM-MSC functions for the restoration of gastric CSCs in vitro.

BM-MSC Tumor Microenvironment and Gastric CSCs

\section{BM-MSCs Mediate in vivo Tumorigenicity and Pluripotency of GC Cells}

Based on the hypothesis that cohesion with BM-MSC provides a stimulus for CSC properties, we carried out tumor development experiments using a mouse xenograft model. MKN-7 cells, UE6E7T-12 BM-MSCs and a mixture of the two, were injected into SCID mice subcutaneously. The mean tumor volume of the MKN-7/ UE6E7T-12 (coinjection) xenografts was much larger than that of the MKN-7 xenografts, but UE6E7T-12 alone did not develop any subcutaneous tumors (fig. $4 \mathrm{a}, \mathrm{b}$ ). In addition, a limiting dilution assay revealed that the MKN-7/ UE6E7T-12 (coinjection) xenografts showed 8.5-fold higher tumorigenicity than the MKN-7 xenografts 4 weeks after injection (table 1). Notably, proliferation of spindle-shape MSCs was detected within the MKN-7/ UE6E7T-12 (coinjection) xenografts by histological examination, which demonstrated positive immunoreactivity against human-specific vimentin (fig. 4c), suggesting that these stroma were derived from coinoculated UE6E7T-12 BM-MSCs. Moreover, the negativity for abnormal nuclear accumulation of $\mathrm{p} 53$ protein denied the possibility that the stroma was composed by the EMT of MKN-7 cells (that express mutant p53 protein) [36], and detection of the E7 gene by genomic PCR supported the coexistence of UE6E7T-12 BM-MSCs within the tumor (online suppl. fig. S5). Simultaneously, increased numbers of CD133+ MKN-7 cells were detected in the MKN-7/UE6E7T-12 (coinjection) xenografts, particularly nearby the vimentin+ UE6E7T-12 BM-MSCs (fig. 4c). Although the MKN7 xenografts did not express markers for the colon epithe-

Pathobiology 2012;79:290-306 297 
Fig. 4. Coinjection of UE6E7T-12 BMMSCs restores properties of CSCs of MKN-7 cells in vivo. a SCID mouse xenograft model subcutaneously injected with MKN-7 cells, UE6E7T-12 BM-MSCs and the mixture of both. $\mathbf{b}$ Growth curves of subcutaneous xenografts. No tumor formation was found in SCID mice injected with UE6E7T-12 cells. c Histological examination of subcutaneous xenografts. The MKN-7/UE6E7T-12 (coinjection) tumors were accompanied by proliferation of UE6E7T-12 BM-MSCs. Immunofluorescence was performed to detect E-cadherin, vimentin and CD133. Nuclei were stained with DAPI. d Restoration of pluripotency of subcutaneous xenografts. Expressions of CD10, MUC2, Chromogranin $\mathrm{A}$ and villin are demonstrated. $\mathrm{Nu}-$ clei were stained with DAPI. Areas within dotted lines show UE6E7T-12 BM-MSCsderived stroma.

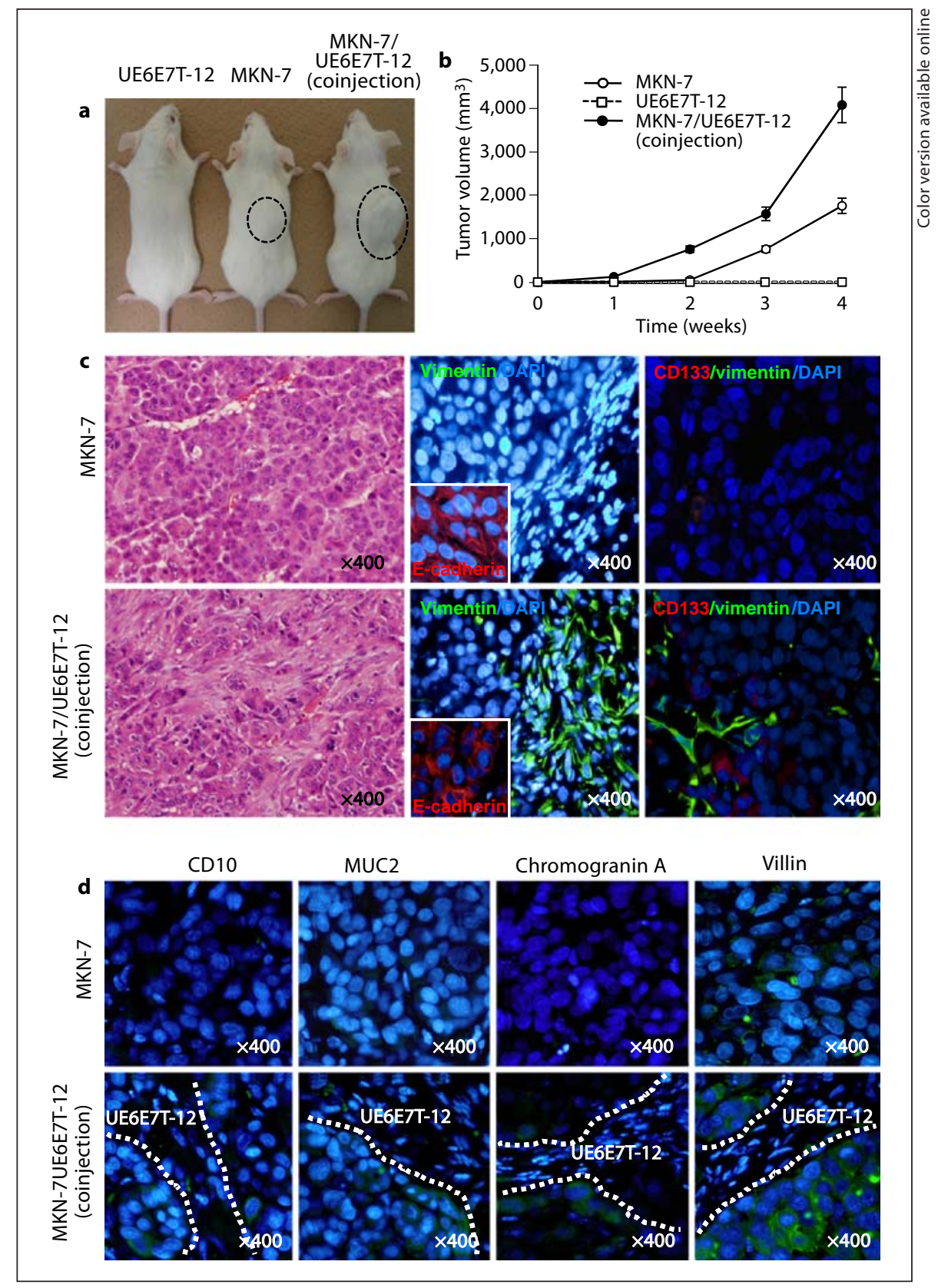

lium (CD10 and MUC2), neuroendocrine cells (Chromogranin A) and small intestine (villin), restoration of multilineage differentiation potential was detected in the MKN-7/UE6E7T-12 (coinjection) xenografts (fig. 4d).

\section{Profiles of Genes Induced by Direct Contact with $B M-M S C s$}

To identify intracellular signaling pathways that are related to re-acquisition of CSCs, differential gene expression profiling was conducted in MKN-7 cells in the pres- ence or absence of coincubation with BM-MSCs. Total RNAs derived from MKN-7 cells (original, CD133+ and CD133-) with or without coculture with UE6E7T-12 BMMSCs were prepared, as well as that from MKN-7 cells treated with the conditioned medium of UE6E7T-12 BMMSCs. After treating MACS with anti-EpCAM antibody, we confirmed that the total RNAs extracted did not contain RNAs from UE6E7T-12 BM-MSCs by RT-PCR of E7 mRNA (online suppl. fig. S6). The change in the gene expression profiles of the MKN-7 cells (original, CD133+ 
Table 2. Genes differentially upregulated in GC-derived MKN-7 cells (original, CD133+ and CD133-) in the presence or absence of coculture with UE6E7T-12 BM-MSCs

\begin{tabular}{|c|c|c|c|c|c|}
\hline Gene ID & $\begin{array}{l}\text { Gene } \\
\text { symbol }\end{array}$ & Gene description & Gene ID & $\begin{array}{l}\text { Gene } \\
\text { symbol }\end{array}$ & Gene description \\
\hline \multicolumn{3}{|c|}{ Extracellular matrix } & \multicolumn{3}{|c|}{ Cytoskeleton and cell motility (continued) } \\
\hline NM_000088 & COL1A1 & collagen, type I, alpha 1 & NM_003289 & TPM2 & tropomyosin 2 \\
\hline NM_000089 & COL1A2 & collagen, type I, alpha 2 & NM_006009 & TUBA1A & tubulin, alpha 1a \\
\hline NM_000090 & COL $3 A 1$ & collagen, type III, alpha 1 & NM_004385 & VCAN & versican \\
\hline $\begin{array}{l}\text { NM_000093 } \\
\text { NM } 000393\end{array}$ & $\begin{array}{l}\text { COL5A1 } \\
\text { COL5A2 }\end{array}$ & $\begin{array}{l}\text { collagen, type } \mathrm{V} \text {, alpha } 1 \\
\text { collagen, type } \mathrm{V} \text {, alpha } 2\end{array}$ & \multicolumn{3}{|l|}{ EMT-related } \\
\hline NM_001848 & COL6A1 & $\begin{array}{l}\text { Collagen, type } V \text {, alpha } 2 \\
\text { collagen, type VI, alpha } 1\end{array}$ & NM_003068 & SNAI2 & snail homolog 2 (Slug) \\
\hline NM_004369 & COL6A3 & collagen, type VI, alpha 3 & NM_003380 & $V I M$ & vimentin \\
\hline NM_133507 & $D C N$ & decorin & NM_212476 & FN1 & fibronectin 1 \\
\hline \multirow[t]{2}{*}{ NM_004105 } & \multirow[t]{2}{*}{ EFEMP1 } & \multirow{2}{*}{$\begin{array}{l}\text { EGF-containing fibulin-like extracellular matrix } \\
\text { protein } 1\end{array}$} & \multicolumn{3}{|c|}{ Growth factors and cytokines } \\
\hline & & & NM_174556 & IGFBP3 & insulin-like growth factor binding protein 3 \\
\hline NM_000138 & $F B N 1$ & fibrillin 1 & NM_001901 & CTGF & connective tissue growth factor \\
\hline NM_002345 & $L U M$ & lumican & NM_002192 & INHBA & inhibin, beta $\mathrm{A}$ \\
\hline $\begin{array}{l}\text { NM_032348 } \\
\text { NM_012293 }\end{array}$ & $\begin{array}{l}\text { MXRA8 } \\
\text { PXDN }\end{array}$ & $\begin{array}{l}\text { matrix-remodelling associated } 8 \\
\text { peroxidasin homolog }\end{array}$ & NM_000609 & CXCL12 & chemokine (C-X-C motif) ligand 12 \\
\hline NM_000362 & TIMP3 & TIMP metallopeptidase inhibitor 3 & \multicolumn{3}{|c|}{ Intracellular signaling } \\
\hline \multirow{2}{*}{$\begin{array}{l}\text { NM_000602 } \\
\text { NM_003118 }\end{array}$} & \multirow{2}{*}{$\begin{array}{l}\text { SERPINE1 } \\
\text { SPARC }\end{array}$} & 1 serpin peptidase inhibitor, clade $\mathrm{E}$, member 1 & NM_181690 & AKT3 & $\mathrm{v}$-akt murine thymoma viral oncogene homolog \\
\hline & & $\begin{array}{l}\text { secreted protein, acidic, cysteine-rich } \\
\text { (osteonectin) }\end{array}$ & 6441 & $C$ & $\begin{array}{l}3 \\
\text { cysteine rich transmembrane BMP }\end{array}$ \\
\hline \multicolumn{3}{|c|}{ Cell-matrix interaction and cell-cell adhesion } & 013372 & GREM1 & gremlin 1, cysteine knot superfamily, homolog \\
\hline NM_033664 & $\mathrm{CDH} 11$ & cadherin 11 , type $2, \mathrm{OB}$-cadherin & NM_000428 & LTBP2 & $\begin{array}{l}\text { latent transforming growth factor beta binding } \\
\text { protein } 2\end{array}$ \\
\hline NM_001554 & CYR61 & cysteine-rich, angiogenic inducer, 61 & NM_006868 & RAB31 & RAB31, member RAS oncogene family \\
\hline NM_006039 & $M R C 2$ & mannose receptor, $\mathrm{C}$ type 2 & NM_005613 & RGS4 & regulator of G-protein signaling 4 \\
\hline NM_002317 & LOX & lysyl oxidase & NM_000358 & TGFBI & transforming growth factor, beta-induced \\
\hline NM_003246 & THBS1 & thrombospondin 1 & NM_003392 & WNT5A & wingless-type MMTV integration site family, \\
\hline $\begin{array}{l}\text { NM_003247 } \\
\text { NM } 022648\end{array}$ & $\begin{array}{l}\text { THBS2 } \\
\text { TNS1 }\end{array}$ & $\begin{array}{l}\text { thrombospondin } 2 \\
\text { tensin } 1\end{array}$ & & & member $5 \mathrm{~A}$ \\
\hline \multirow[t]{2}{*}{ NM_001627 } & $A L C A M$ & activated leukocyte cell adhesion molecule & Others & & \\
\hline & & $(\mathrm{CD} 166)$ & NM_021913 & $A X L$ & AXL receptor tyrosine kinase \\
\hline \multirow[t]{2}{*}{ NM_006317 } & BASP1 & brain abundant, membrane attached signal & NM_004772 & C5orf13 & chromosome 5 open reading frame 13 \\
\hline & $D S E$ & $\begin{array}{l}\text { protein } 1 \\
\text { dermatan sulfate epimerase }\end{array}$ & NM_002318 & ENTPD4 & ectonucleoside triphosphate diphosphohydrolase \\
\hline $\begin{array}{l}\text { NM_013352 } \\
\text { NM_000165 }\end{array}$ & $\begin{array}{l}\text { DSE } \\
\text { GJA1 }\end{array}$ & $\begin{array}{l}\text { dermatan sulfate epimerase } \\
\text { gap junction protein, alpha } 1\end{array}$ & NM 006832 & FERMT2 & $\begin{array}{l}4 \\
\text { fermitin family }\end{array}$ \\
\hline NM_015170 & SULF1 & sulfatase 1 & NM 002167 & ID3 & $\begin{array}{l}\text { lermitin family homolog } 2 \\
\text { inhibitor of DNA binding } 3\end{array}$ \\
\hline NM_002998 & $S D C 2$ & syndecan 2 & NM_018847 & KLHL9 & kelch-like 9 \\
\hline \multicolumn{3}{|c|}{ Cytoskeleton and cell motility } & NM_006475 & POSTN & periostin, osteoblast specific factor \\
\hline NM_001613 & АCTA2 & actin, alpha 2, smooth muscle, aorta & NM_000961 & PTGIS & prostaglandin I2 synthase \\
\hline NM_005159 & ACTC1 & actin, alpha, cardiac muscle 1 & NM_002852 & PTX3 & $\begin{array}{l}\text { pentraxin-related gene, rapidly induced by } \mathrm{IL}-1 \\
\text { beta }\end{array}$ \\
\hline NM_033138 & $C A L D 1$ & caldesmon 1 & NM 004598 & SPOCK1 & $\begin{array}{l}\text { beta } \\
\text { sparc/osteonectin, cwcv and kazal-like } 1\end{array}$ \\
\hline NM_007085 & FSTL1 & follistatin-like 1 & NM_002727 & SRGN & serglycin \\
\hline NM_005909 & MAP1B & microtubule-associated protein $1 \mathrm{~B}$ & NM_003186 & TAGLN & transgelin \\
\hline NM_016081 & PALLD & palladin, cytoskeletal associated protein & & & \\
\hline
\end{tabular}

Genes with $>2$-fold differential expression across all three comparisons in the original, CD133+ and CD133- MKN-7 cells in the presence or absence of coculture with UE6E7T-12 BM-MSCs are shown. A total of 65 genes was identified by Venn diagram overlapping of altered transcripts (fig. 5a). Folds changes detected by cDNA microarray in the original, CD133+ and CD133- MKN-7 cells are shown in supplementary tables 1, 2 and 3, respectively.

and CD133-) cocultured with UE6E7T-12 BM-MSCs in comparison to the cells without coculture did not involve a large number of genes (online suppl. table 1-3). After normalization of raw data and exclusion of genes altered by treatment with the conditioned medium of UE6E7T-12 BM-MSCs, a total of 65 genes was finally determined to be significantly upregulated $48 \mathrm{~h}$ after direct contact with
UE6E7T-12 BM-MSCs (fig. 5a, table 2). In the microarray data, the mRNA levels of wingless-type MMTV integration site family member 5A (WNT5A [NM_003392]), transforming growth factor- $\beta$ (TGF- $\beta$ )-induced (TGFBI [NM 000358]), Snail homolog 2 (Slug [NM_003068]), v-akt murine thymoma viral oncogene homolog 3 (AKT3 [NM_181690]) and inhibitor of DNA binding 3 (ID3 
Fig. 5. Identification of genes upregulated by the presence of coculture with UE6E7T-12 BM-MSCs in MKN-7 cells (original, CD133+ and CD133-) by microarray analysis. a Venn diagram of genes upregulated by cell-cell contact with UE6E7T-12 BM-MSCs in the original, CD133+ and CD133- MKN-7 mRNA pools. Numbers of candidate genes in each area are shown. b Results of quantitative real-time RT-PCR analysis. To confirm the results of microarray analysis, five genes (WNT5A, TGFBI, Slug, AKT3 and ID3) were chosen. The mRNAs were prepared from MKN-7 cells: coculture (+) versus coculture (-) and CD133+ versus CD133MKN-7 cells. Relative differences in each test are shown numerically.
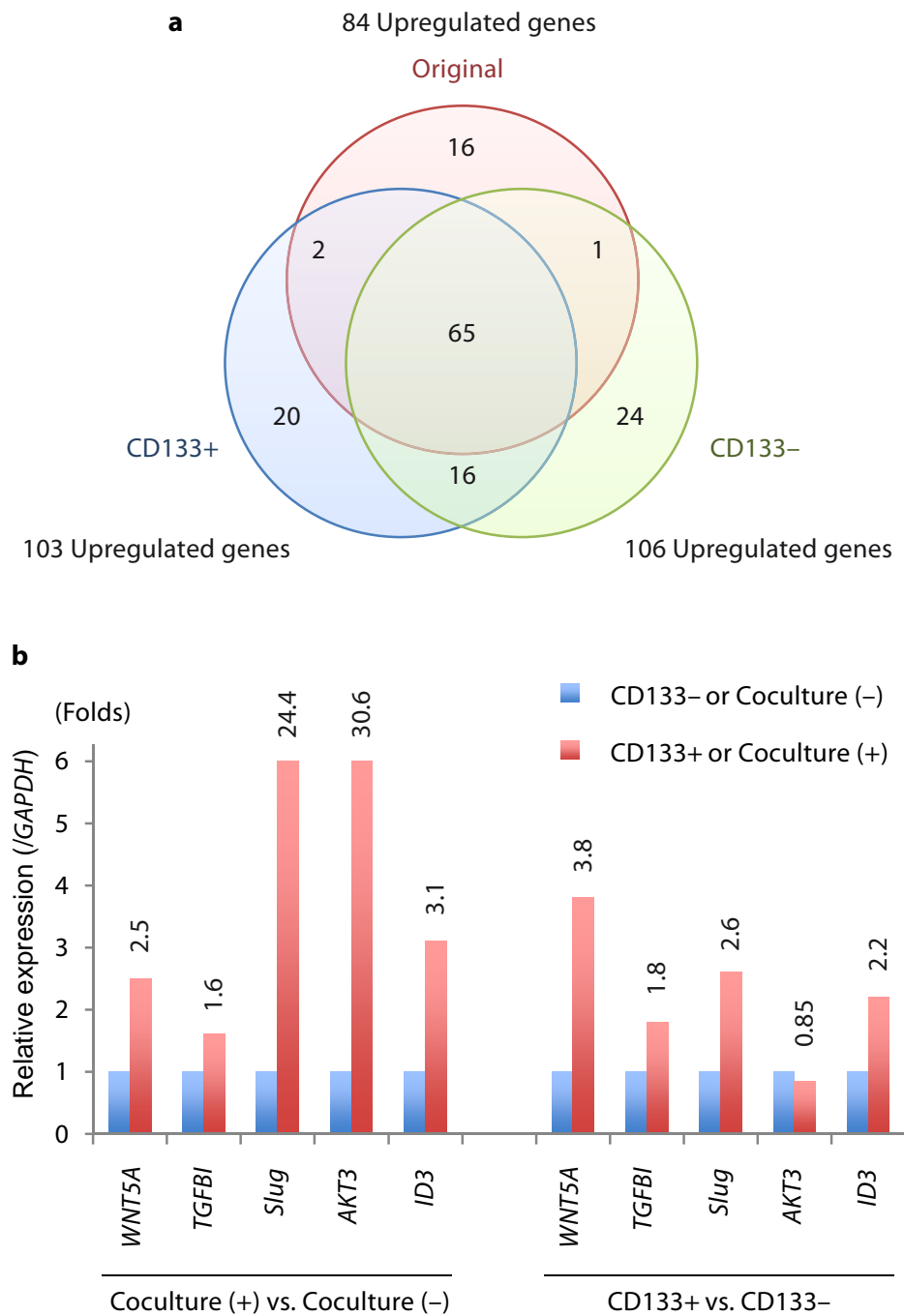

Fig. 6. Recombinant WNT5A and TGF- $\beta 1$ restores CD133+ MKN-7 cells. a Cell-cell contact by coincubation increased WNT5A expression in MKN-7 cells and TGF- $\beta 1$ expression in UE6E7T-12 BM-MSCs. b Concentration of TGF- $\beta 1$ detected by ELISA in the conditioned medium of coincubation of MKN-7 cells and UE6E7T-12 BM-MSCs. c Induction of CD133 expression by treatment with recombinant WNT5A $(500 \mathrm{ng} / \mathrm{ml})$ and TGF- $\beta 1$ $(10 \mathrm{ng} / \mathrm{ml})$. As a control, recombinant WNT3A protein $(500 \mathrm{ng} /$ $\mathrm{ml}$ ) was also used. d WNT5A and TGF- $\beta 1$ increases CD133+ MKN-7 cells in vitro. Forty-eight hours after treatment, cells were divided into CD133+ and CD133- cells. Recombinant WNT3A protein was also used as a control. e Recombinant WNT5A and coculture with BM-MSCs increases CD133+ MKN-7 cells via WNT5A- $\beta$-catenin signaling. MKN-7 cells treated with WNT5A or cocultured with UE67T-12 BM-MSCs were maintained in the presence or absence of WNT inhibitor XAV939 (1 $\mu \mathrm{M})$ for $48 \mathrm{~h}$. f Recombinant TGF- $\beta 1$ and coculture with BM-MSCs increases CD133+ MKN-7 cells via TGF- $\beta$-Smad4 signaling. MKN-7 cells treated with TGF- $\beta 1$ or cocultured with UE67T-12 BM-MSCs were maintained in the presence or absence of TGF- $\beta$ inhibitor SB431542 (50 pM) for $48 \mathrm{~h}$. 


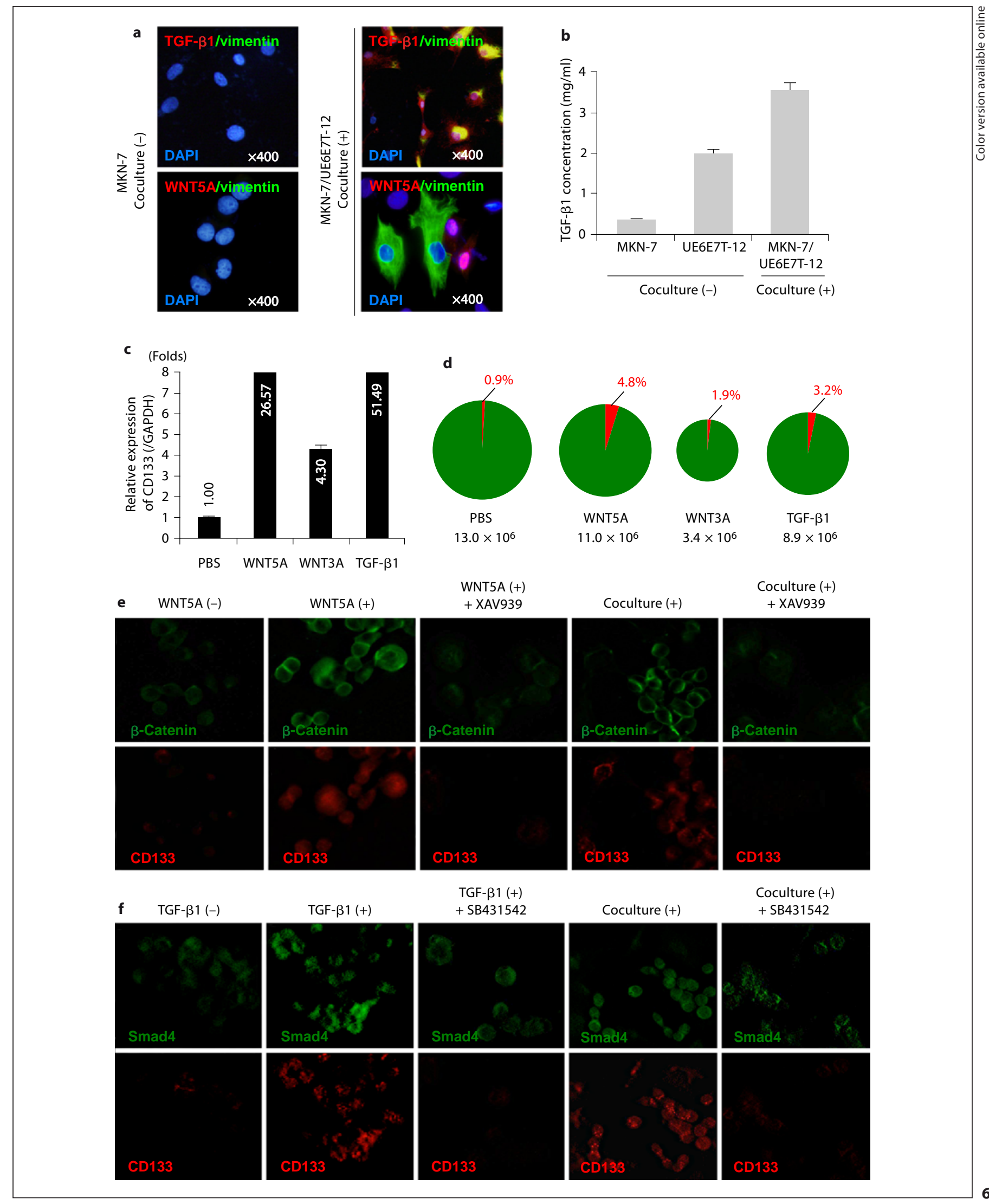

BM-MSC Tumor Microenvironment and

Pathobiology 2012;79:290-306 
a

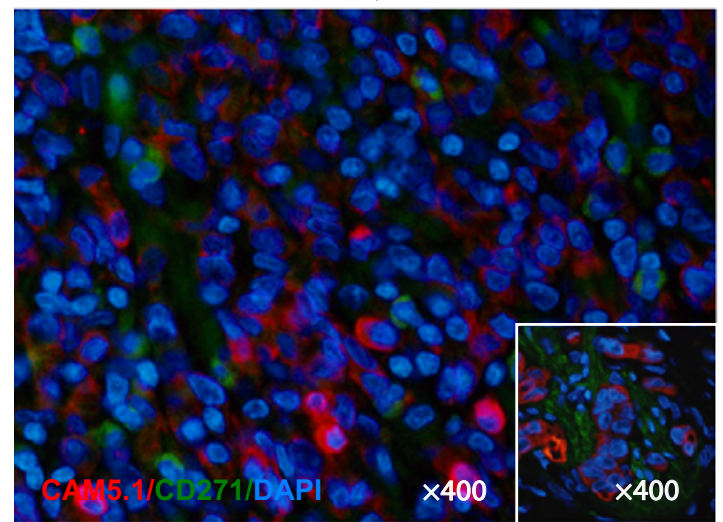

b
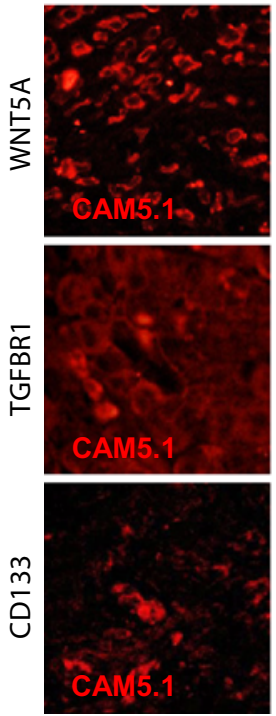

Diffuse-type GC
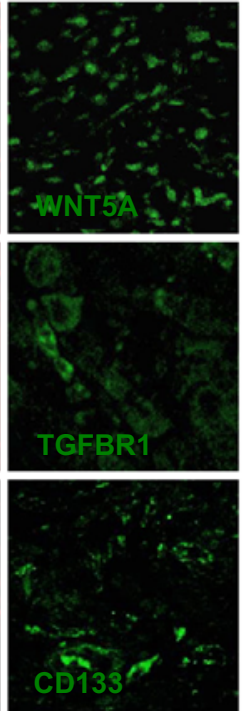
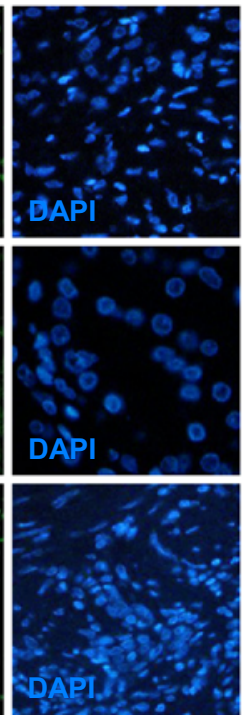

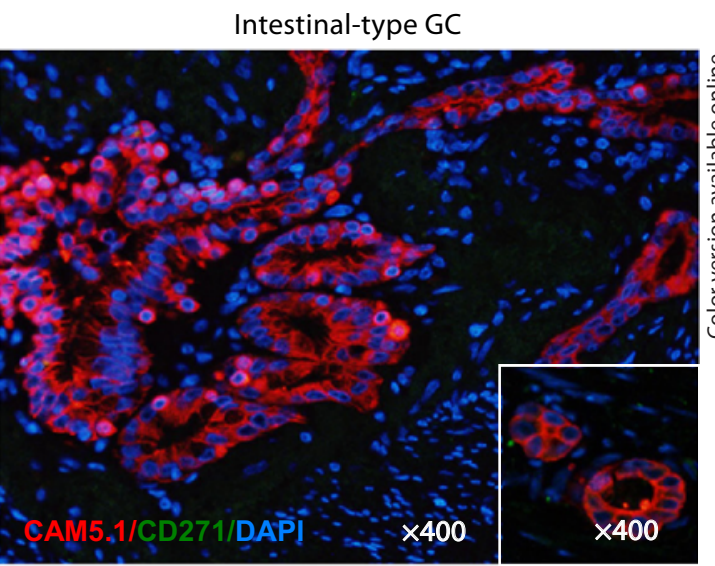

Intestinal-type GC
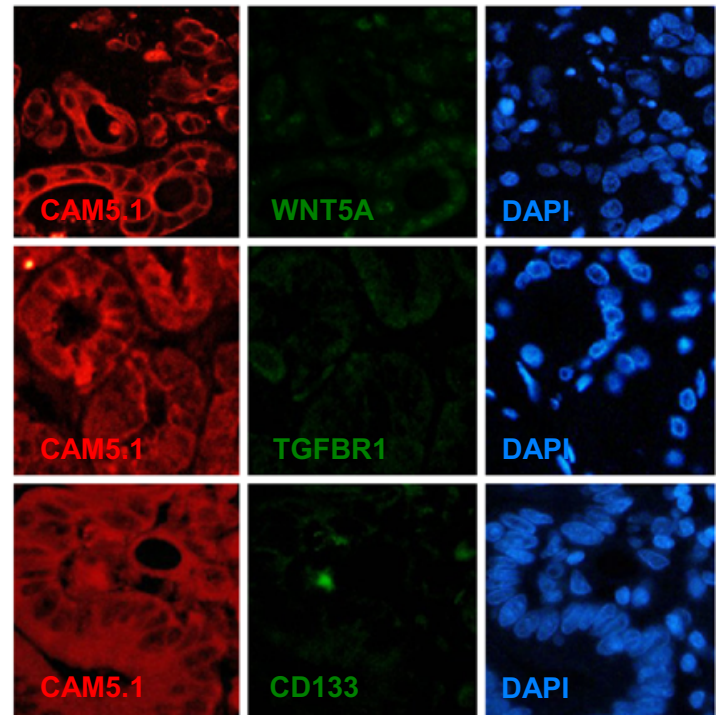

Fig. 7. BM-MSCs provides an advantageous tumor microenvironment for restoration of CSC properties in human GC tissues. a Recruitment of CD271+ BM-MSCs within diffuse-type GC tumors but not within intestinal-type GC tumors. The GC cells used were immunostainined with anti-CAM 5.1 antibody and nuclei were stained by DAPI. $\mathbf{b}$ The status of WNT5A, TGFBR1 and CD133 expression in diffuseand intestinal-type GC tumors. The GC cells used were immunostained with antiCAM 5.1 antibody and the nuclei were stained by DAPI. c A schematic model of the cell-cell interaction between GC cells and BM-MSCs.

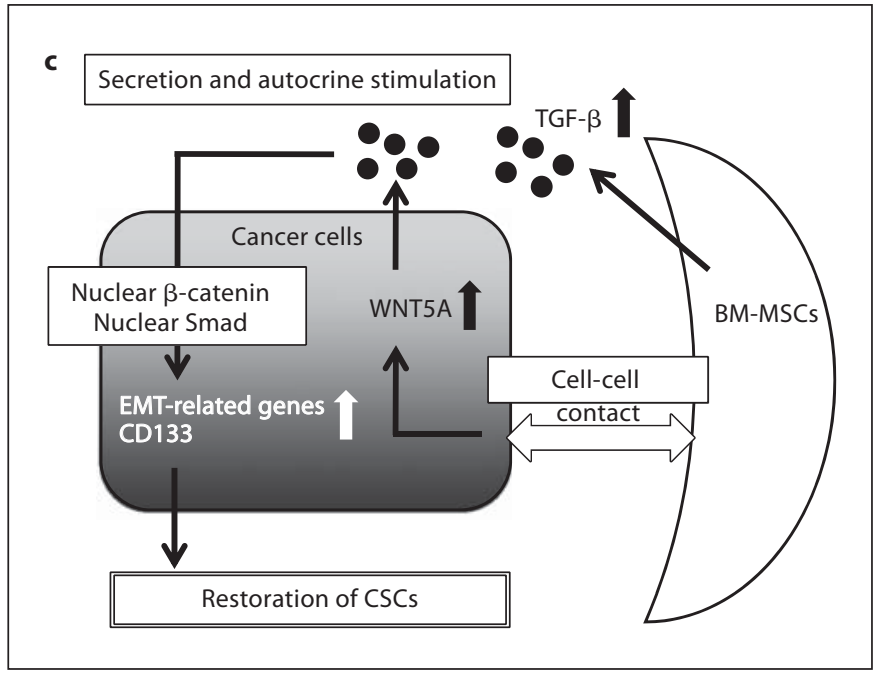


Table 3. Subcutaneous in vivo tumor development experiments of CD133+ and CD133 - cells sorted from MKN-7 cells into SCID mice

\begin{tabular}{llll}
\hline $\begin{array}{l}\text { Cells per } \\
\text { injection }\end{array}$ & $\begin{array}{l}\text { TGF-1, CD133+ } \\
\text { incidence (\%) }\end{array}$ & $\begin{array}{l}\text { WNT5A } \\
\text { CD133+ } \\
\text { incidence }(\%)\end{array}$ & $\begin{array}{l}\text { No treatment } \\
\text { CD133+ } \\
\text { incidence }(\%)\end{array}$ \\
\hline $1 \times 10^{7}$ & $-(-)$ & $-(-)$ & $4 / 4(100)$ \\
$1 \times 10^{6}$ & $-(-)$ & $-(-)$ & $4 / 4(100)$ \\
$1 \times 10^{5}$ & & $4 / 4(100)$ & $4 / 4(75)$ \\
$1 \times 10^{4}$ & $4 / 4(100)$ & $4 / 4(100)$ & $2 / 4(75)$ \\
$1 \times 10^{3}$ & $3 / 4(75)$ & $1 / 4(25)$ & $-(-)$ \\
$1 \times 10^{2}$ & $2 / 4(50)$ & $1 / 269$ & $1 / 4,579$ \\
\hline Frequency & $1 / 458$ & $1 / 76-1 / 886$ & $1 / 1,531-1 / 13,691$ \\
Folds change & $1 / 153-1 / 1,369$ & & \\
\hline
\end{tabular}

SCID mice were injected with $1 \times 10^{3}, 1 \times 10^{4}, 1 \times 10^{5}, 1 \times$ $10^{6}$ and $1 \times 10^{7}$ cells. They were monitored for 4 weeks and scored as positive (palpable tumor) or negative. Establishment of xenografts was evaluated by histological examination.

[NM_002167]) in the two comparative studies of MKN-7 cells, CD133+ versus CD133- and coculture(+) versus coculture(-), showed good concordance (fig. 5b).

WNT5A and TGF- $\beta$ Is Responsible for Reacquisition of CD133+ GC Cells

WNT signaling has been reported to involve in CSC self-renewal, EMT and metastasis [37], and transduction of WNT5A into GC-derived cells contributes to increasing metastatic potential in vitro and in vivo [38]. Also, autocrine TGF- $\beta$ signaling involving the TGF- $\beta$-Smad and TGF- $\beta$-Sox pathways is necessary for the maintenance of glioma-initiating cells $[39,40]$. Therefore, among the candidates of genes responsible for the restoration of CSC properties of MKN-7 cells, we focused on the WNT5A and TGFBI genes. In fact, coculture of MKN-7 cells and UE6E7T-12 BM-MSCs induced WNT5A expression in MKN-7 cells and TGF- $\beta 1$ expression in UE6E7T-12 cells, respectively (fig. 6a). In addition, by ELISA, an increased concentration of TGF- $\beta 1$ in the conditioned medium was detected when UE6E7T-12 BM-MSCs were coincubated with MKN-7 cells (fig. 6b). Of note, treatment of CD133- MKN-7 cells with recombinant WNT5A and TGF- $\beta 1$ not only upregulated CD133 mRNA expression levels (fig. 6c) but also increased the population of CD133+ cells and the number of MKN-7 cells (fig. $6 \mathrm{~d}$ ). To confirm the significance of the WNT and TGF- $\beta$ signaling pathways mediated by cocultured UE6E7T-12 BM-MSCs, WNT inhibitor XAV939 and TGF- $\beta$ inhibitor SB431542 were employed. These inhibitors suppressed induction of $\beta$-catenin and Smad 4 by recombinant WNT5A and TGF$\beta 1$, as well as the induction of CD133 (fig. 6e, f). Also, coculture with UE6E7T-12 BM-MSCs activated both the WNT- $\beta$-catenin and TGF- $\beta$-Smad signaling pathways, which were inhibited by additional XAV939 and SB431542, respectively (fig. 6e, f). Finally, we examined the in vivo tumorigenicity of WNT5A- and TGF- $\beta 1$-induced CD133+ MKN-7 cells, and confirmed that the induced CD133+ cells had a high tumorigenic potential (table 3 ).

\section{Recruitment of BM-MSCs in Diffuse-Type GC}

The involvement of the WNT and TGF- $\beta$ signaling pathways in human diffuse-type GC has been well documented: WNT5A is known to be frequently detected in diffuse-type GC and WNT5A siRNA suppresses cell migration [41], and disruption of TGF- $\beta$ signaling reduces stromal fibrosis [42]. Thus, we finally attempted to detect BM-MSC in diffuse-type GC tissues using the BM-MSC marker CD271 [43]. The average numbers of CD271+ mesenchymal cells within diffuse-type and intestinal-type GC tissues were 12.6 and 1.8 at 10 high power fields, respectively (fig. 7a; p < 0.001). Moreover, CAM5.1+ GC cells in diffuse-type GC tissues showed abundant WNT5A and TGF- $\beta$ type I receptor (TGFBR1) expression, suggesting that cancer cells in diffuse-type GCs potentially have autocrine stimulation of WNT5A and a high sensitivity against extracellular TGF- $\beta$ stimuli (fig. $7 b$ ). Furthermore, frequent positivity of CD133 was detected in diffuse-type GC tissues, which was significantly different from those in intestinal-type GC tissues (fig. 7b).

\section{Discussion}

Regarding the cancer-stroma interaction which activates local invasion and distant metastasis of cancer cells, two distinct mechanisms have been proposed: the efferent pathway mediated by various cancer-derived soluble factors that cause differentiation of the stroma cells and angiogenesis, and the afferent pathway triggered by direct heterotypic cell-cell contacts or through diffusible molecules from the stroma cells [1]. We previously examined the biological roles of molecular cross-talk between GC cells and gastric fibroblasts and found that direct cellcell contact with 'orthotopic' fibroblasts promotes EMT of GC cells [5]. In this study, strikingly, coincubation with UE6E7T-12 BM-MSCs not only induced cell-cell contact with MKN-7 cells but also upregulated the proliferation of MKN-7 cells, significantly more than did coincu- 
bation with differentiated UE6E7T-12 BM-MSCs or gastric fibroblast NF-23. In addition, direct contact with UE6E7T-12 BM-MSCs, but not with conditioned medium, altered gene expressions of epithelial, mesenchymal and CSC markers, indicating EMT and the restoration of the stemness of GC cells. These results suggest that BMMSCs may demonstrate peculiar impacts on GC cells within the tumor microenvironment. The origin of CAFs remains controversial: fibroblasts are considered to be the main progenitor cells of CAFs, but recruitment of progenitors of myofibroblasts [44] and transdifferentiated epithelial cancer cells within tumors have also been experimentally proved [45]. However, taken together with the existence in human cancer tissues of CD34+ fibrocytes originating from myeloid precursors in the bone marrow [46, 47], bone marrow is likely a source of CAFs. Our findings provide evidence of the specific effects of BM-MSCs during the progression and development of cancer cells, particularly in diffuse-type GCs. Notably, subcutaneous tumors derived from the mixture of MKN7 cells and UE6E7T-12 BM-MSCs showed that proliferation of UE6E7T-12 BM-MSC-derived mesenchymal cells and CD271+ cells was observed only in diffuse-type GC tissues, strongly suggesting the contribution of BM-MSCs in the pathogenesis of diffuse-type GCs.

As for the involvement of the CAF-mediated culturing condition of CSCs, established CAFs enriched self-renewal, spheroid-forming and multipotential differentiation in Lin- SCA-1+ CD49f+ prostate CSCs [48]. However, we show that BM-MSC mediated the restoration of CD133+ MKN-7 cells, resulting in higher tumorigenicity and pluripotency. In colorectal cancer, it has been documented that interleukin-6, secreted by BM-MSCs, increased the numbers of CSCs and promoted tumor formation in vitro and in vivo [49]. To the best of our knowledge, this is the first report to demonstrate the role of BM-MSCs in the conversion of gastric non-CSCs into CSCs. Also, this interconvertibility would frustrate attempts to cure tumors by eliminating CSCs alone, as the therapeutic elimination of CSCs may be followed by their regeneration from residual non-CSCs, allowing tumor regrowth and clinical relapse. Recently, Quintana et al. [31] demonstrated the tumorigenicity of unselected melanoma cells using an experimental model of transplantation of a single human melanoma cell into NOD/SCID Il $2 \mathrm{rg}^{-/-}$mice and showed that tumorigenic potential is not a specific character of CSCs but is present also in 'common' non-CSCs. However, they did not exclude the possible interconvertibility between non-CSCs and CSCs and the incomplete ability of known CSC markers to en- rich tumorigenic cells [50]. We therefore think that BMMSCs can provide an advantageous tumor microenvironment for the restoration and maintenance of CSCs. The BM-MSC-induced autocrine effects of WNT5A and the paracrine effect of TGF- $\beta 1$ on the restoration of CD133+ CSCs supports the importance of a cancer niche for the maintenance of CSCs. Furthermore, Sato et al. [30] reported that leucine-rich repeat-containing G-protein coupled receptor 5+ (Lgr5+) of cycling crypt base columnar cells from the colon showed self-renewal and crypt-villus structures in vitro without a mesenchymal niche; however, the long-term culture condition used in the experiment contained WNT agonist R-spondin 1, EGF and bone-morphogenic protein 4 antagonist Noggin, contrarily indicating the necessity of regulation of the WNT and TGF- $\beta$ signaling pathways for the self-organizing structures. To elucidate the molecular mechanisms of cancer aggressiveness and chemoresistance associated with CSCs, an understanding of the tumor microenvironment is indispensable.

Activation of Frizzled receptors by WNT ligands disrupts the APC- $\beta$-catenin complex and results in the translocation of $\beta$-catenin to the nucleus, where it associates with the T-cell factor (Tcf)/lymphoid enhance factor (Lef) transcription factor to activate specific WNT target genes [51]. Using a WNT- $\beta$-catenin-Tcf/Lef reporter system, it has been documented that WNT signaling activity is a marker for colon CSCs and is regulated by myofibroblast-secreted hepatocyte growth factor in nearby colon cancer cells [52]. This may also support our conclusion that the stemness of GC cells is orchestrated by the microenvironment. However, in this study, the WNT- $\beta$-catenin signaling pathway seemed to be activated by autocrine effects of WNT5A in GC cells. High expression of WNT5A was previously detected in diffuse-type GCs [41], and WNT5A was shown to activate liver metastasis [38], but these researchers did not investigate gastric CSCs that would give meaning to this aggressiveness of GC cells. In addition, TGF- $\beta$ binds to type I and type II receptors (TGFBR1 and TGFBR2) and transduces intracellular signals principally through Smad proteins, regulatory Smads (R-Smads, Smad2 and Smad3) form heteromeric complexes with common-partner Smad (Co-Smad, Smad4), translocate into the nucleus, and regulate the expression of various target genes [53]. In recent research, it has been documented that TGF- $\beta$ is necessary for glioma-initiating cell self-renewal and tumorigenicity in vitro and in vivo [39, 40]. Shinto et al. [54] showed frequent expressions of TGFBR1, TGFBR2 and phospho-Smad2 in diffuse-type GCs, and TGFBR1 kinase inhibitor Ki26894 ef- 
fectively decreased invasion/motility and the EMT of diffuse-type GCs. Although they did not analyze the role of Ki26894 on gastric CSC viability, our findings suggest that TGF- $\beta$ has an essential role in the regulation of gastric CSCs and would therefore be a therapeutic strategy against diffuse-type GCs (fig. 7c). We also examined the effects of WNT5A and TGF- $\beta$ in other GC cell lines. Both WNT5A and TGF- $\beta$ increased the numbers of CD133+ CSCs, but the effects were not significant (data not shown). The efficacy of CSC restoration by WNT5A and TGF- $\beta$ may be influenced by the nature of each GC cell line.

In our previous study, interaction with gastric fibroblasts induced EMT in diffuse-type GC-derived HSC-39 cells: cell-cell contact with mesenchymal cells induced Snail expression with decreased E-cadherin expression and increased vimentin expression in HSC-39 cells, which was followed by immunohistochemistry of diffuse-type GC tissues [5]. Interestingly, accumulating evidence suggests that both WNT5A and TGF- $\beta$ play critical roles on induction of EMT in cancer cells: transduction of WNT5A induced a spindle shape accompanied by decreased E-cadherin expression and increased vimentin expression in melanoma cells [55], and TGF- $\beta$-driven EMT was regulated by the Snail-Smad3/4 complex, which functions as a repressor to E-cadherin expression [56]. Indeed, in this study, coincubation with UE6E7T-12 BMMSCs increased Snail and vimentin expressions, but the decrease of E-cadherin expression was not significant. Nevertheless, even in the absence of UE6E7T-12 BMMSCs, treatment with WNT5A and TGF- $\beta$ effectively increased the Snail-family transcription factors Snail, Slug, Twist 1 and Twist2 (online suppl. fig. S7). These findings suggest a direct link between the EMT and the gain of CSC properties [57]. Although further investigation will be required to clarify the relationship between CSC and EMT, our data imply that BM-MSCs may mediate the tumor microenvironment not only at the primary tumor site but also at metastatic sites, and that the WNT5A and TGF- $\beta$ induced by BM-MSCs could be therapeutic targets in the controlling the aggressiveness, chemoresistance and metastatic potential of human malignancies, particularly in diffuse-type GCs.

\section{Acknowledgement}

This work was supported by Grant-in-Aid for Scientific Research (C-19590347 and C-21590370) from the Japan Society for the Promotion of Science.

\section{References}

1 De Wever O, Mareel M: Role of tissue stroma in cancer cell invasion. J Pathol 2003;200: 429-447.

- 2 Hwang RF, Moore T, Arumugam T, Ramachandran V, Amos KD, Rivera A, Ji B, Evans DB, Logsdon CD: Cancer-associated stromal fibroblasts promote pancreatic tumor progression. Cancer Res 2008;68:918-926.

3 Meads MB, Gatenby RA, Dalton WS: Environment-mediated drug resistance: a major contributor to minimal residual disease. Nat Rev Cancer 2009;9:665-674.

4 Park CC, Zhang H, Pallavicini M, Gray JW, Baehner F, Park CJ, Bissell MJ: $\beta 1$ integrin inhibitory antibody induces apoptosis of breast cancer cells, inhibits growth, and distinguishes malignant from normal phenotype in three-dimensional cultures and in vivo. Cancer Res 2006;66:1526-1535.

-5 Semba S, Kodama Y, Ohnuma K, Mizuuchi E, Masuda R, Yashiro M, Hirakawa K, Yokozaki $\mathrm{H}$ : Direct cancer-stromal interaction increases fibroblast proliferation and enhances invasive properties of scirrhous-type gastric carcinoma cells. Br J Cancer 2009;101:1365-1373.

-6 Sanz-Rodriguez F, Hidalgo A, Teixido J: Chemokine stromal cell-derived factor- $1 \alpha$ modulates VLA-4 integrin-mediated multiple myeloma cell adhesion to CS-1/fibronectin and VCAM-1. Blood 2001;97:346-351.
7 Azab AK, Azab F, Blotta S, Pitsillides CM, Thompson B, Runnels JM, Roccaro AM, Ngo HT, Melhem MR, Sacco A, Jia X, Anderson KC, Lin CP, Rollins BJ, Ghobrial IM: RhoA and Racl GTPases play major and differential roles in stromal cell-derived factor-1-induced cell adhesion and chemotaxis in multiple myeloma. Blood 2009;114:619-629.

$\checkmark 8$ Karnoub AE, Dash AB, Vo AP, Sullivan A, Brooks MW, Bell GW, Richardson AL, Polyak K, Tubo R, Weinberg RA: Mesenchymal stem cells within tumour stroma promote breast cancer metastasis. Nature 2007; 449:557-563.

\9 Mishra PJ, Mishra PJ, Humeniuk R, Medina DJ, Alexe G, Mesirov JP, Ganesan S, Glod JW, Banerjee D: Carcinoma-associated fibroblast-like differentiation of human mesenchymal stem cells. Cancer Res 2008;68:43314339.

10 Caplan AI: Mesenchymal stem cells. J Orthop Res 1991:9:641-650.

11 Caplan AI: Mesenchymal stem cell: cellbased reconstructive therapy in orthopaedics. Tiss Eng 2005;11:1198-1211.

12 Caplan AI: Adults mesenchymal stem cells for tissue engineering versus regenerative medicine. J Cell Physiol 2007;213:341-347.

$\checkmark 13 \mathrm{Wu}$ Y, Chen L, Scott PG, Tredget EE: Mesenchymal stem cells enhance wound healing through differentiation and angiogenesis. Stem Cells 2007;25:2648-2659.

14 Heppner GH, Miller BE: Tumor heterogeneity: biological implications and therapeutic consequences. Cancer Metastasis Rev 1983; 2:5-23.

15 Nowell PC: The clonal evolution of tumor cell populations. Science 1976;194:23-28.

16 Campbell LL, Polyak K: Breast tumor heterogeneity: cancer stem cell or clonal evolution? Cell Cycle 2007;6:2332-2338.

17 Clarke MF, Fuller M: Stem cells and cancer: two faces of Eve. Cell 2006;124:1111-1115.

18 Polyak K, Hahn WC: Roots and stems: stem cells in cancer. Nat Med 2006;12:296-300.

19 Ishikawa F, Yoshida S, Saito Y, Hijikata A, Kitamura H, Tanaka S, Nakamura R, Tanaka T, Tomiyama H, Saito N, Fukata M, Miyamoto T, Lyons B, Ohshima K, Uchida N, Taniguchi S, Ohara O, Akashi K, Harada M, Shultz LD: Chemotherapy- resistant human AML stem cells home to and engraft within the bone-marrow endosteal region. Nat Biotechnol 2007;25:1315-1321.

20 Dalerba P, Dylla SJ, Park IK, Liu R, Wang X, Cho RW, Hoey T, Gurney A, Huang EH, Simeone DM, Shelton AA, Parmiani G, Castelli C, Clarke MF: Phenotypic characterization of human colorectal cancer stem cells. Proc Natl Acad Sci USA 2007;104:10158-10163. 
21 Vermeulen L, Todaro M, de Sousa Mello F, Sprick MR, Kemper K, Perez Alea M, Richel DJ, Stassi G, Medema JP: Single-cell cloning of colon cancer stem cells reveals a multi-lineage differentiation capacity. Proc Natl Acad Sci USA 2008;105:13427-13432.

-22 Schatton T, Murphy GF, Frank NY, Yamaura K, Waaga-Gasser AM, Gasser M, Zhan Q, Jordan S, Duncan LM, Weishaupt C, Fuhlbrigge RC, Kupper TS, Sayegh MH, Frank $\mathrm{MH}$ : Identification of cells initiating human melanomas. Nature 2008;451:345-349.

-23 Singh SK, Hawkins C, Clarke ID, Squire JA, Bayani J, Hide T, Henkelman RM, Cusimano MD, Dirks PB: Identification of human brain tumour initiating cells. Nature 2004;432: 396-401.

-24 O’Brien CA, Pollett A, Gallinger S, Dick JE: A human colon cancer cell capable of initiating tumour growth in immunodeficient mice. Nature 2007;445:106-110.

25 Ma S, Chan KW, Hu L, Lee TK, Wo JY, Ng IO, Zheng BJ, Guan XY: Identification and characterization of tumorigenic liver cancer stem/progenitor cells. Gastroenterology 2007;132:2542-2556

-26 Olempska M, Eisenach PA, Ammerpohl O, Ungefroren H, Fandrich F, Kalthoff H: Detection of tumor stem cell markers in pancreatic carcinoma cell lines. Hepatobiliary Pancreat Dis Int 2007;6:92-97.

-27 Vander Griend DJ, Karthaus WL, Dalrymple S, Meeker A, DeMarzo AM, Isaacs JT: The role of CD133 in normal human prostate stem cells and malignant cancer-initiating cells. Cancer Res 2008;68:9703-9711.

-28 Yin AH, Miraglia S, Zanjani ED, AlmeidaPorada G, Ogawa M, Leary AG, Olweus J, Kearney J, Buck DW: AC133, a novel marker for human hematopoietic stem and progenitor cells. Blood 1997;90:5002-5012.

29 Bidlingmaier S, Zhu X, Liu B: The utility and limitations of glycosylated human CD133 epitopes in defining cancer stem cells. J Mol Med 2008;86:1025-1032.

-30 Sato T, Vries RG, Snippert HJ, van de Wetering $\mathrm{M}$, Barker N, Stange DE, van Es JH, Abo A, Kujala P, Peters PJ, Clevers H: Single Lgr5 stem cells build crypt-villus structures in vitro without a mesenchymal niche. Nature 2009;459:262-265.

-31 Quintana E, Shackleton M, Sabel MS, Fullen DR, Johnson TM, Morrison SJ: Efficient tumour formation by single human melanoma cells. Nature 2008;456:593-598.

32 Hojo H: Establishment of cultured cell lines of human stomach cancer origin and their morphological characteristics (article in Japanese). J Niigata Exptl Med 1977;91:737-763.

- 33 Takeuchi M, Takeuchi K, Ozawa Y, Kohara A, Mizusawa H: Aneuploidy in immortalized human mesenchymal stem cells with nonrandom loss of chromosome 13 in culture. In Viro Cell Dev Biol Anim 2009;45:290-299.

34 Japanese Gastric Cancer Association: Japanese Classification of Gastric Carcinoma, ed 13. Tokyo, Kanehara Co, 1999.
55 Menon LG, Picinich S, Koneru R, Gao H, Lin SY, Koneru M, Mayer-Kuckuk P, Glod J, Banerjee D: Differential gene expression associated with migration of mesenchymal stem cells to conditioned medium from tumor cells or bone marrow cells. Stem Cells 2007; 25:520-528.

36 Yokozaki H: Molecular characteristics of eight gastric cancer cell lines established in Japan. Pathol Int 2000;50:767-777.

- 37 DiMeo TA, Anderson K, Phadke P, Fang C, Perou CM, Naber S, Kuperwasser C: A novel lung metastasis signature links Wnt signaling with cancer cell self-renewal and epithelial-mesenchymal transition in basal-like breast cancer. Cancer Res 2009;69:53645373.

38 Yamamoto H, Kitadai Y, Yamamoto H, Oue N, Ohdan H, Yasui W, Kikuchi A: Laminin $\gamma 2$ mediates Wnt5a-induced invasion of gastric cancer cells. Gastroenterology 2009;137: 242-252.

39 Ikushima H, Todo T, Ino Y, Takahashi M, Miyazawa M, Miyazono K: Autocrine TGF$\beta$ signaling maintains tumorigenicity of glioma-initiating cells through Sry-related HMG-box factors. Cell Stem Cell 2009;5: 504-514.

40 Peñuelas S, Anido J, Prieto-Sanchez RM, Folch G, Barba I, Cuartas I, García-Dorado D, Poca MA, Sahuquillo J, Baselga J, Seoane J: TGF- $\beta$ increases glioma-initiating cell self-renewal through the induction of LIF in human glioblastoma. Cancer Cell 2009;15: 315-327.

-41 Kurayoshi M, Oue N, Yamamoto H, Kishida M, Inoue A, Asahara T, Yasui W, Kikuchi A: Expression of Wnt-5a is correlated with aggressiveness of gastric cancer by stimulating cell migration and invasion. Cancer Res 2006;66:10439-10448.

42 Komuro A, Yashiro M, Iwata C, Morishita Y, Johansson E, Matsumoto Y, Watanabe A, Aburatani H, Miyoshi H, Kiyono K, Shirai YT, Suzuki HI, Hirakawa K, Kano MR, Miyazono K: Diffuse-type gastric carcinoma: Progression, angiogenesis, and transforming growth factor beta signaling. J Natl Cancer Inst 2009; 101:592-604.

43 Bieback K, Hecker A, Kocaömer A, Lannert H, Schallmoser K, Strunk D, Klüter H: Human alternatives to fetal bovine serum for the expansion of mesenchymal stromal cells from bone marrow. Stem Cells 2009;27: 2331-2341.

-44 Rønnov-Jessen L, Petersen OW, Koteliansky VE, Bissell MJ: The origin of the myofibroblasts in breast cancer: recapitulation of tumor environment in culture unravels diversity and implicates converted fibroblasts and recruited smooth muscle cells. J Clin Invest 1995;95:859-873.

45 Oft M, Akhurst RJ, Balmain A: Metastasis is driven by sequential elevation of $\mathrm{H}$-ras and Smad2 levels. Nat Cell Biol 2002;4:487-494.

-46 Barth PJ, Ebrahimsade S, Hellinger A, Moll $\mathrm{R}$, Ramaswamy A: CD34 ${ }^{+}$fibrocytes in neoplastic and inflammatory pancreatic lesions. Virchows Arch 2002;440:128-133.
47 Nakayama H, Enzan H, Miyazaki E, Kuroda N, Naruse K, Hiroi M: Differential expression of CD34 in normal colorectal tissue, peritumoral inflammatory tissue, and tumour stroma. J Clin Pathol 2006;53:626629.

-48 Liao CP, Adisetiyo H, Liang M, Roy-Burman $P$ : Cancer-associated fibroblasts enhance the gland-forming capability of prostate cancer stem cells. Cancer Res 2010;70:7294-7303.

49 Tsai KS, Yang SH, Lei YP, Tsai CC, Chen HW, Hsu CY, Chen LL, Wang HW, Miller SA, Chiou SH, Hung MC, Hung SC: Mesenchymal stem cells promote formation of colorectal tumors in mice. Gastroenterology 2011;141:1046-1056.

50 Chen R, Nishimura MC, Bumbaca SM, Kharbanda S, Forrest WF, Kasman IM, Greve JM, Soriano RH, Gilmour LL, Rivers CS, Modrusan Z, Nacu S, Guerrero S, Edgar KA, Wallin JJ, Lamszus K, Westphal M, Heim S, James CD, VandenBerg SR, Costello JF, Moorefield S, Cowdrey CJ, Prados M, Phillips HS: A hierarchy of self-renewing tumor-initiating cell types in glioblastoma. Cancer Cell 2010;17:362-375.

51 Tetsu O, McCormick F: $\beta$-catenin regulates expression of cyclin D1 in colon carcinoma cells. Nature 1999;398:422-426.

52 Vermeulen L, De Sousa E Melo F, van der Heijden M, Cameron K, de Jong JH, Borovski T, Tuynman JB, Todaro M, Merz C, Rodermond H, Sprick MR, Kemper K, Richel DJ, Stassi G, Medema JP: Wnt activity defines colon cancer stem cells and is regulated by the microenvironment. Nat Cell Biol 2010; 12:468-476.

53 Massagué J: TGF- $\beta$ in cancer. Cell 2008;134: 215-230.

54 Shinto O, Yashiro M, Kawajiri H, Shimizu K, Shimizu T, Miwa A, Hirakawa K: Inhibitory effect of a TGF $\beta$ receptor type-I inhibitor, Ki26894, on invasiveness of scirrhous gastric cancer cells. Br J Cancer 2010;102:844-851.

55 Dissanayake SK, Wade M, Johnson CE, O'Connell MP, Leotlela PD, French AD, Shah KV, Hewitt KJ, Rosenthal DT, Indig FE, Jiang Y, Nickoloff BJ, Taub DD, Trent JM, Moon RT, Bittner M, Weeraratna AT: The Wnt5A/protein kinase C pathway mediates motility in melanoma cells via the inhibition of metastasis suppressors and initiation of an epithelial to mesenchymal transition. J Biol Chem 2007;282:17259-17271.

56 Vincent T, Neve EP, Johnson JR, Kukalev A, Rojo F, Albanell J, Pietras K, Virtanen I, Philipson L, Leopold PL, Crystal RG, de Herreros AG, Moustakas A, Pettersson RF, Fuxe J: A SNAIL1-SMAD3/4 transcriptional repressor complex promotes TGF- $\beta$ mediated epithelial-mesenchymal transition. Nat Cell Biol 2009;11:943-950.

57 Mani SA, Guo W, Liao MJ, Eaton EN, Ayyanan A, Zhou AY, Brooks M, Reinhard F, Zhang CC, Shipitsin M, Campbell LL, Polyak $\mathrm{K}$, Brisken C, Yang J, Weinberg RA: The epithelial-mesenchymal transition generates cells with properties of stem cells. Cell 2008; 133:704-715. 